\title{
New Records of Vascular Plants in the Yukon Territory VI
}

\author{
William J. Cody ${ }^{1}$, Catherine E. Kennedy ${ }^{2}$, Bruce BennetT ${ }^{2}$, and Phil Caswell ${ }^{3}$ \\ ${ }^{1}$ Biodiversity, National Program on Environmental Health, Agriculture and Agri-Food Canada, Wm. Saunders Building (49), \\ Central Experimental Farm, Ottawa, Ontario K1A 0C6 Canada \\ ${ }^{2}$ Department of Environment, Government of the Yukon, Box 2703, Whitehorse, Yukon Y1A 2C6 Canada \\ ${ }^{3}$ P. O. Box 91, Roxbury, New York 12474 USA
}

Cody, William J., Catherine E. Kennedy, Bruce Bennett, and Phil Caswell. 2004. New records of vascular plants in the Yukon Territory VI. Canadian Field-Naturalist 118(4): 558-578.

Based on field reconnaissance mainly in 2002 in the southern part of the Yukon and particularly in and adjacent to Kluane National Park, information is provided on geographically significant plant occurrences. Six native taxa, Atriplex alaskensis, Claytonia megarrhiza, Corispermum ochotense var. alaskanum, Oxytropis arctica, Polemonium acutiflorum forma lacteum and Polemonium boreale forma albiflorum, and four introduced taxa. Arabis caucasica, Camelina sativa, Senecio eremophilus, and Setaria viridis are reported new to the known flora of the Yukon Territory. Significant range extensions for 158 native and 21 introduced taxa are included. Parrya arctica, Armoracia rusticana, Atriplex patula and Papaver nudicaule ssp. nudicaule are excluded from the Yukon flora.

Key Words: Vascular plants, Yukon Territory, flora, new records, range extensions, phytogeography.

Since the writing of New Records of Vascular Plants in the Yukon Territory V (Cody et al. 2003), a considerable number of plant specimens have been submitted to Cody for identification and confirmation. The major submissions include the following locations and collectors: (1) Kluane National Park and vicinity by Phil Caswell for the National Park Service as part of ongoing botanical inventories; (2) W. J. Cody and Catherine Kennedy spent four days collecting specimens in the Fort Selkirk area assessing the flora of that region; (3) W. J. Cody and Margaret Cody studied changed vegetation along the southern highways; (4) Bruce Bennett conducted studies adjacent to the North Canol Road, assisting with rare plant surveys for YukonCharley Rivers National Park and interesting areas while boating down the Yukon River; (5) Rhonda Rosie visited sites adjacent to Nisling Lake and Morris Lake for the Yukon Territory Government and Parks Branch; (6) Stu Withers visited former mine sites at Atlin Lake and Deadman Creek in connection with reclamation of vegetation and soil stabilization; (7) with his continuing interest in vegetation habitats Greg Brunner collected plant specimens from areas adjacent to the Klondike River and Dawson City.

This paper serves to further update the Flora of the Yukon Territory (Cody 1996) and Flora of the Yukon Territory, Second Edition (Cody 2000) along with other records recently published (Cody et al. 1998, 2000, 2001, 2002, 2003). The floristic information presented earlier and updated here is essential for biological research and ongoing work relating to agriculture, forestry, sustainable resource management and wildlife management. With additions of six native and four introduced species reported here, the flora now includes 1181 species. The new native species are all rare (as defined by Douglas et al. 1981).
The taxa addressed in the body of this paper appear in a synoptic list by Yukon status in alphabetical order. The taxa are then discussed in taxonomic order, as presented in the Flora of the Yukon Territory with citation of specimens and other pertinent information. Common names follow Cody (1996) and Douglas et al. (19982001).

\section{Synoptic List by Yukon Status \\ Errata in New Records: (5) \\ Carex stylosa \\ Douglasia arctica \\ Poa nemoralis revised to Poa interior}

Armoracia rusticana revised to Rorippa barbareifolia

Papaver nudicaule ssp. nudicaule revised to Papaver croceum

\author{
Native Taxa New to the Yukon Territory: (6) \\ Atriplex alaskensis \\ Claytonia megarrhiza \\ Corispermum ochotense var. alaskanum \\ Oxytropis arctica \\ Polemonium acutiflorum forma lacteum \\ Polemonium boreale forma albiflorum
}
Introduced Taxa New to the Yukon Territory: (4)
Arabis caucasica
Camelina sativa
Senecio eremophilus
Setaria viridis
Range Extensions of Native Taxa within the Yukon
Territory: (158)
Agrostis filiculmis
Allium schoenoprasum ssp. sibiricum
Alyssum obovatum
Amelanchier alnifolia
Arabis holboellii var. retrofracta
Arabis holboellii var. secunda
Aster alpinus ssp. vierhapperi
Aster falcatus 
Atriplex subspicata

Bromus ciliatus

Callitriche anceps

Cardamine bellidifolia

Carex albo-nigra

Carex athrostachya

Carex atrosquama

Carex capillaris ssp. chlorostachys

Carex crawfordii

Carex eleusinoides

Carex foenea

Carex limosa

Carex loliacea

Carex obtusata

Carex pachystachya

Carex pellita

Carex petasata

Carex praegracilis

Carex rossii

Carex supina ssp. spaniocarpa

Carex sychnocephala

Carex viridula

Cassiope tetragona ssp. saximontana

Cerastium arvense

Chamaerhodos erecta ssp. nuttallii

Chenopodium capitatum

Cicuta maculata var. angustifolia

Cryptogramma crispa var. acrostichoides

Deschampsia brevifolia

Descurainia incisa var. incisa

Douglasia alaskana

Draba aurea

Draba corymbosa

Draba crassifolia

Draba glabella

Draba nemorosa

Draba ogilviensis

Draba palanderiana

Draba porsildii

Draba stenoloba

Dryas hookeriana

Eleocharis uniglumis

Elymus alaskanus ssp. alaskanus

Elymus glaucus

Elymus macrourus

Elymus spicatus

Elymus trachycaulus ssp. andinus

Erigeron caespitosus

Erigeron hyperboreus

Eriophorum brachyantherum

Eritrichium aretioides

Eritrichium chamissonis

Euphrasia subarctica

Festuca brachyphylla

Festuca richardsonii

Festuca saximontana

Gentianella tenella

Geum aleppicum ssp. strictum

Geum rossii

Glyceria striata var. stricta

Gymnocarpium jessoense ssp. parvulum

Harrimanella stellariana

Hordeum brachyantherum

Iris setosa ssp. interior

Isoetes echinospora
Isoetes ?maritima

Juncus bufonius

Juncus filiformis

Kobresia simpliciuscula

Koeleria macrantha

Lepidium densiflorum var. densiflorum

Lupinus nootkatensis

Luzula arcuata ssp. unalaschkensis

Maianthemum canadense ssp. interius

Mertensia paniculata var. alaskana

Mimulus guttatus

Minuartia dawsonensis

Minuartia elegans

Minuartia macrocarpa

Minuartia yukonensis

Montia fontana

Myriophyllum verticillatum

Nuphar polysepalum

Orobanche fasciculata

Oxytropis campestris ssp. varians

Pedicularis oederi

Phacelia mollis

Phlox hoodii

Phyllodoce glanduliflora

Pinguicula villosa

Pinus contorta ssp. latifolia

Plantago canescens

Plantago maritima

Poa interior

Poa leptocoma

Poa secunda

Podistera macounii

Polygonum lapathifolium

Potamogeton alpinus ssp. tenuifolius

Potamogeton berchtoldii

Potamogeton gramineus

Potamogeton pectinatus

Potamogeton praelongus

Potamogeton subsibiricus

Potamogeton zosteriformis

Potentilla arguta var. convallaria

Primula eximia

Puccinellia interior

Pulsatilla ludoviciana

Pyrola minor

Ranunculus aquatilis var. subrigidus

Ranunculus occidentalis var. brevistylis

Rhinanathus minor ssp. borealis

Ribes oxyacanthoides ssp. oxyacanthoides

Rorippa barbareifolia

Rosa woodsii

Salix alaxensis ssp. longistylis

Salix glauca var. acutifolia

Salix pseudomyrsinites

Salix rotundifolia ssp. dodgeana

Sambucus racemosa ssp. pubens

Saxifraga caespitosa

Saxifraga eschscholtzii

Saxifraga foliolosa

Saxifraga nelsoniana ssp. pacifica

Saxifraga rufopilosa

Saxifraga tricuspidata

Scirpus rollandii

Silene involucrata ssp. tenella

Silene williamsii 
Solidago canadensis var. salebrosa

Spiranthes romanzoffiana

Stellaria umbellata

Stipa comata

Stipa nelsonii ssp. dorei

Stipa richardsonii

Subularia aquatica ssp. americana

Tofieldia coccinea

Trientalis europaea

Triglochin palustre

Typha latifolia

Urtica dioica ssp. gracilis

Utricularia minor

Vaccinium membranaceum

Vahlodea atropurpurea

Valeriana sitchensis

Vicia americana

Viola renifolia var. brainerdii

Woodsia alpina

Woodsia ilvensis

\section{Range Extensions of Introduced Taxa within the}

Yukon Territory: (21)

Agropyron pectiniforme

Agropyron sibiricum

Agrostis gigantea

Avena sativa

Brassica rapa

Bromus inermis

Capsella bursa-pastoris

Elytrigia intermedia

Galeopsis tetrahit ssp. bifida

Lepidium densiflorum var. macrocarpum

Myosotis scorpioides

Papaver croceum

Pоа аппиа

Rheum rhabarbarum

Rumex crispus

Silene vulgaris

Sinapis arvensis

Sonchus arvensis ssp. uliginosus

Tanacetum vulgare

Thlaspi arvense

Trifolium pratense

Comments on Native Taxa in the Yukon Flora: (3)

Carex stylosa

Douglasia arctica

Isoetes ?maritima

\section{Deletions of Native Taxa from the Yukon Flora: (1)}

Parrya arctica

Deletions of Introduced Taxa from the Yukon Flora:

(3)

Armoracia rusticana

Atriplex patula

Papaver nudicaule ssp. nudicaule

\section{Annotated Species List}

IsOETACEAE

Isoetes echinospora Dur., Bristle-like Quillwort YUKON: On stony shore of small pond south of Morris Lake, 60²0'N 13140'W, R. Rosie 2030, 8 Sept. 1999 (DAO); washed up on lakeshore, northeast shore of Nisling Lake, $62^{\circ} 02^{\prime} 00^{\prime \prime} \mathrm{N} 137^{\circ} 58^{\prime} 30^{\prime \prime} \mathrm{W}, R$. Rosie
02-821, 12 Aug. 2002 (DAO) (determined by D. F. Brunton).

The first specimen cited above is an extension of the known range in the Territory (Cody 1996) of about 180 kilometers southwest of the vicinity of Francis Lake. The second specimen is from a site about 500 kilometers northwest of Frances Lake and about 430 kilometers northwest of the Morris Lake site.

Isoetes ?maritima Underw., Maritime Quillwort YUKON: washed ashore, WNW side of Trout Lake, $68^{\circ} 49^{\prime} 27^{\prime \prime N} 138^{\circ} 45^{\prime} 8^{\prime \prime W}, J$. M. Line 2000-72, 28 July 2000 (DAO) (determined by D. F. Brunton \& D. M. Britton).

The fragmented specimens found washed up along the shore of the lake possessed only immature female spores which were mostly densely tuberculate but could not definitely be determined as I. maritima. If this could be verified by more mature specimens from Trout Lake it would be only the third known location in the Territory and a range extension of about 260 kilometers northwest of Vittrewka Lake (Cody et al. 2001).

Isoetes maritima Underw., Maritime Quillwort - It has been brought to our attention by Lori Schroeder (Environment Yukon) that specimen data according to Greg Brunner's field notebook for his collection \#39-99 which was published in Cody et al. (2001) should be: Peel River Wetland Study Turner Lake, 66ำ1'N 134¹4'W, 2 July 1999.

\section{PTERIDACEAE}

Cryptogramma crispa (L.) R. Br. var. acrostichoides (R. Br.) C. B. Clarke, Mountain-parsley - YUKON: Kluane National Park, south-facing scree slope, $60^{\circ} 06.019^{\prime} \mathrm{N} 137^{\circ} 08.532^{\prime} \mathrm{W}$, P. Caswell 026, 6 June 2002 (DAO).

This rare species which was previously known from only six localities in the Territory is now known from two sites in southern Kluane National Park.

\section{ASPIDIACEAE}

Gymnocarpium jessoense (Koidz.) Koidz. ssp. parvulum Sarvela, Nahanni Oak Fern - YUKON: dry rock outcrop, lower Beaver River, 6009'09"N 124 $55^{\circ} 16^{\prime \prime} \mathrm{W}$, B. Bennett 97-518, 19 Aug. 1997 (B. Bennett Herbarium, photo DAO).

The specimen cited above of this rare plant in the Territory is an extension of the known range of about 300 kilometers from a site in the vicinity of Francis Lake (Cody 1996).

Woodsia alpina (Bolton) S. F. Gray, Northern Woodsia YUKON: damp organic soil in rock crevice, Cache Lake, Kluane National Park, $61^{\circ} 12.5866^{\prime} \mathrm{N} 139^{\circ} 03.671$ 'W, $P$. Caswell 575, 24 July 2002 (DAO).

The specimen cited above is an extension of the known range in the Territory of about 45 kilometers southwest of a site at the north end of Kluane Lake and is new to the flora of Kluane National Park.

Woodsia ilvensis (L.) R. Br., Rusty Woodsia - YuKON: steep south-facing bluffs along Klondike River, Dawson Area, 1 mile north of $64^{\circ} 02^{\prime} \mathrm{N} 137^{\circ} 41^{\prime} 30^{\prime \prime} \mathrm{W}, G$. Brunner 435, 2 June 2001 (DAO); dry rocky outcrop, 
S Fork bluffs, Klondike River, $64^{\circ} 01^{\prime} \mathrm{N} 138^{\circ} 9^{\prime} \mathrm{W}, G$. Brunner 443-01, 14 July 2001 (DAO).

Douglas et al. (1981) considered this species rare in the Territory. The specimens cited above are from sites about 60 kilometers southwest of a site adjacent to the Dempster Highway mapped by Cody (1996).

\section{PinACEAE}

Pinus contorta Dougl. ex Loud. ssp. latifolia Engelm. ex S. Wats., Lodgepole Pine - YukON: roadside, North Canol Road KM 284, 62 ${ }^{\circ} 13^{\prime} 02^{\prime \prime} \mathrm{N} 131^{\circ} 46^{\prime} 10^{\prime \prime} \mathrm{W}, B$. Bennett 02-723, 22 Sept. 2002 (DAO); roadside across road from large truck dump, North Canol Road Km $380,62^{\circ} 50^{\prime} 03^{\prime \prime} \mathrm{N} 130^{\circ} 56^{\prime} 24^{\prime \prime} \mathrm{W}$, B. Bennett 02-724, 21 Sept. 2002 (DAO).

The specimens cited above are an extension of the known range in the Territory of about 175 kilometers northeast of a site adjacent to the South Canol Road. The second specimen was from a site adjacent to an old house and may have been planted.

\section{TYPHACEAE}

Typha latifolia L., Common Cattail - YUKON: border of small lake below swimming pool, Takhini Hot Spring, 60 $52^{\prime} 40.7^{\prime \prime N} 135^{\circ} 21^{\prime} 30.6^{\prime \prime} \mathrm{W}$, Cody \& Cody 37692, 10 Aug. 2001 (DAO); same locality (fruiting) Cody 38311, 4 Aug. 2002 (DAO).

Douglas et al. (1981) considered this species rare in the Territory. Cody (1996) knew it only from the vicinity of Mayo. Cody et al. $(2000,2001)$ added additional sites in the extreme southeast and in the vicinity of Faro. The specimen cited above which was collected just west of Whitehorse is now from the fourth site in the Territory.

\section{POTAMOgETONACEAE}

Potamogeton alpinus Balbis ssp. tenuifolius (Raf.) Hultén - YUKON: plant fragments washed ashore, Trout Lake, $68^{\circ} 50^{\prime} \mathrm{N} 138^{\circ} 45^{\prime} \mathrm{W}$, J. M. Line 2000-9, 29 July 2000 (DAO).

The specimen cited above is the northernmost yet found in the Territory. It is an extension of the known range (Cody 1996) of about 85 kilometers NE of a site north of latitude $68^{\circ} \mathrm{N}$.

Potamogeton berchtoldii Fieb. - YUKON: shallow water of small lake, west side of Dempster Highway $\mathrm{Km}$ 93, 64 $39^{\prime} 01 " \mathrm{~N} 138^{\circ} 23^{\prime} 01 " \mathrm{~W}$, Cody \& Cody 38060, 27 July 2002 (DAO).

The specimen cited above is from a site about 80 kilometers northeast of Dawson City. To the north a single site was previously known from adjacent to the Peel River (Cody 1996).

Potamogeton gramineus L., Variable-leaved Pondweed - YukON: slough off Yukon River with old sunken dredge, $61^{\circ} 56^{\prime} 35^{\prime \prime} \mathrm{N} 135^{\circ} 12^{\prime} 17^{\prime \prime} \mathrm{W}$, B. Bennett 02-299, 7 Aug. 2002 (DAO).

The nearest site to that listed above known to Cody (1996) is about 75 kilometers to the north.

Potamogeton pectinatus L., Sago Pondweed - YUKON: shallow backwater, Dezadeash River, Kluane National Park, $60^{\circ} 45.683^{\prime} \mathrm{N} 137^{\circ} 36.010^{\prime} \mathrm{W}$, P. Caswell 805, 16 Aug. 2002 (DAO); locally common in mucky alka- line pond, Mile 985 Alaska Highway, $60^{\circ} 48^{\prime} \mathrm{N}$ $136^{\circ} 45^{\prime} \mathrm{W}$, Calder \& Kukkonen 28277, 14 Aug. 1960 (DAO).

The specimens cited above extend the known range in the Territory about 120 kilometers west of the vicinity of Whitehorse. The Caswell specimen is the first known from Kluane National Park.

Potamogeton praelongus Wulf., White-stemmed Pondweed - YukON: Enoch Lake, Old Crow Flats, $68^{\circ} 05^{\prime} 00^{\prime \prime} \mathrm{N} 140^{\circ} 09^{\prime} 50 " \mathrm{~W}$, B. Bennett 95-413, 10 Aug. 1995 (B. Bennett Herbarium, photo DAO); plant fragments washed ashore, Trout Lake, $68^{\circ} 50^{\prime} \mathrm{N}$ $138^{\circ} 45^{\prime} \mathrm{W}$, J. M. Line 2000-140, 28 July 2000 (DAO); Nordenskiold River wetland pond, M. Dennington, Nord \#23, 19 July 1984 (B. Bennett Herbarium, photo DAO).

Douglas et al. (1981) considered this species rare in the Yukon Territory based on specimens from only two locations. Cody (1996) knew it from five locations. Cody et al. (2000) added three locations. The first specimen cited above is a northwestward extension of about 40 kilometers from the vicinity of Old Crow. The second specimen from about 115 kilometers NNE of Old Crow is the northernmost yet found in the Territory. The third specimen is an extension of the known range in the south of about 125 kilometers northwest of a site just north of Whitehorse.

Potamogeton subsibiricus Hagstr. - YUKON: growing in about 3 feet of water, lake west of Dempster Rd. near mile 65, R. T. Porsild 317, 25 July 1966 (AKA, photo DAO) (determined by A. Batten).

Cody (1996) knew this rare species in the Territory from a single collection from adjacent to the North Canol Road about 450 kilometers to the southeast of the locality cited above.

Potamogeton zosteriformis Fern., Flatstemmed Pondweed - YUKON: in water by outlet of pond, Pumphouse Pond, $3 \mathrm{~km} \mathrm{~S}$ of Alaska Highway, 60 $43^{\prime} 31.3^{\prime \prime} \mathrm{N}$ $135^{\circ} 09^{\prime} 58.3 " \mathrm{~W}$, W. J. Cody 38290, 3 Aug. 2002 (DAO).

Cody (1996) knew this rare species in the Territory from only two localities, one southeast of Haines Junction and one just north of $64^{\circ} \mathrm{N}$. Cody et al. $(1998,2000$ and 2001) added two sites in the south and one north of $68^{\circ} \mathrm{N}$.

\section{SCHEUCHZERIACEAE}

Triglochin palustre L., Marsh Arrow-grass - YUKON: silty river bank with Carex utriculata, C. aquatilis and Juncus alpinoarticulatus, Selwyn, Yukon River, $62^{\circ} 48^{\prime} 06^{\prime \prime N ~ 138} 15 ' 29 " \mathrm{~W}$, B. Bennett 02-294, 9 Aug. 2002 (DAO).

The specimen cited above is between sites adjacent to the Alaska Highway, Klondike Highway and Dawson City.

\section{PoACEAE (GRAminEAE)}

Agropyron pectiniforme R. \& S., Crested Wheat Grass - YUKON: lake shore, Earn Lake, $62^{\circ} .9^{\prime} 08.3^{\prime \prime} \mathrm{N}$ $134^{\circ} 23^{\prime} 07.6 " \mathrm{~W}$, G. Brunner 557-01, 5 Aug. 2001 (DAO); steep stony slope on east side of highway, Haines Highway, $60^{\circ} 6^{\prime} 3.2^{\prime \prime} \mathrm{N} 136^{\circ} 54^{\prime} 51^{\prime \prime} \mathrm{W}$, Cody \& Cody 37911, 21 July 2002 (DAO). 
The first specimen of this introduced species cited above is from a site between the northernmost mapped by Cody (1996) in the vicinity of Mayo and a site adjacent to Faro. The second specimen cited above is an extension of the known range in the Territory of about 85 kilometers southeast of a site in the vicinity of Haines Junction.

Agropyron sibiricum (Willd.) P. Beauv. - YUKON: top of bank overlooking road into gravel pit south of Alaska Highway, 60 49'58"N 135 45'49"W, Cody \& Cody 38210, 1 Aug. 2002 (DAO).

Cody (1996) knew this introduced species in the Territory only from two locations, Whitehorse and Carmacks. A third site was reported from the vicinity of Ross River (Cody et al. 2003). The specimen cited above is from a site about 40 kilometers west of Whitehorse.

Agrostis filiculmis M. E. Jones - YUKON: open area abandoned placer mine, Mechanic Creek, $62^{\circ} 20.1^{\prime} \mathrm{N}$ $137^{\circ} 21.5^{\prime} \mathrm{W}, S$. Withers SW01-062, 6 July 2001 (DAO).

The specimen cited above is only the second known in the Territory (Cody 1996) and is from a site about 200 kilometers southeast of the first site in the vicinity of Dawson City.

Agrostis gigantea Roth., Creeping Bent Grass YuKON: Spruce Hill Park, border of playground at head of Engelman Drive, Whitehorse, 60 36'40.3"N 134 $55^{\prime} 08.8^{\prime \prime W}$, W. J. Cody 37743, 14 July 2002 (DAO).

Cody (1996) knew this introduced species in the Territory from only two localities, Dawson City and Carmacks. An additional collection from a mine site east of Dawson City was reported by Cody et al. (2003). The specimen cited above is from only the fourth known locality in the Territory.

Avena sativa L., Oats - YUKON: scattered in grass area around Beringia Museum, Whitehorse, 60 42'36"N 135 4'45"W, Cody \& Cody 38105, 30 July 2002 (DAO).

Cody (1996) knew this introduced species from only widely separated sites in the Territory, vicinity of Mayo, middle of North Canol Road and east of Watson Lake.

Bromus ciliatus L. - YUKON: in moist moss on mountain slope above treeline on east side of Dempster Highway about 9 kilometers north of Tombstone Park Campsite, 643' $49^{\prime \prime N} 138^{\circ} 15^{\prime} 30^{\prime \prime} \mathrm{W}$, Cody \& Cody 38047, 26 July 2002 (DAO).

The specimen cited above is at the northern limit of this species in the Territory (Cody 1996). The nearest sites previously mapped were about 120 kilometers to the west adjacent to the Yukon River and about 150 kilometers to the southeast in the vicinity of Stewart Crossing. This species was considered rare in the Territory by Douglas et al. (1981).

Bromus inermis Leyss., Smooth Brome - YUKON: sand beach, Kusawa Lake Campground, 60 $5^{\prime} 10^{\prime \prime} \mathrm{N}$ 136 ${ }^{\circ} 42^{\prime \prime} \mathrm{W}$, Cody \& Cody 38144, 31 July 2002 (DAO); gravel ditch between road and steep gravel slope, Haines Highway, 606'3.3"N 136 54'51"W, Cody \& Cody 37912, 21 July 2002 (DAO).

The specimens cited above of this introduced species which are from sites about 100 kilometers southeast of Haines Junction and southwest of Whitehorse, are the most southwestern yet found in the Territory.
Deschampsia brevifolia $\mathrm{R}$. Br. - YUKON: flats 7 miles east of Tagish Bridge, 60¹9'5"N 134 10'17"W, Cody \& Cody 37940, 23 July 2002 (DAO).

The specimen cited above is an extension of the known range in the Territory (Cody 1996) of about 90 kilometers southeast of a site west of Whitehorse.

Elymus alaskanus (Scribn. \& Merr.) A. Löve ssp. alaskanus - YUKON: in sandy soil of river bank, Nisutlin River Delta National Wildlife Area, $60^{\circ} 11^{\prime} \mathrm{N}$ $132^{\circ} 35^{\prime} \mathrm{W}$, B. Bennett 98-167, 26 July 1998 (DAO).

The specimen cited above is an extension of the known range in the Territory of about 180 kilometers south of a site adjacent to the northern South Canol Road.

Elymus glaucus Buckl., Western Rye Grass - YUKON: roadstop in disturbed gravelly soil, Atlin Road just north of BC border, 6000'09"N 133 $47^{\prime} 42.1^{\prime \prime} \mathrm{W}$, Cody \& Cody 37547, 28 July 2001 (DAO)

Douglas et al. (1981) considered this species rare in the Territory. The specimen cited above is an extension of about 115 kilometers southeast of a site adjacent to Whitehorse reported by Cody et al. (2002).

Elymus macrourus (Turcz.) Tzvelev - YUKON: growing in loose sand on riverbar, Wind River, camp \#6, $65^{\circ} 40.46$ 'N $135^{\circ} 11.76^{\prime} \mathrm{W}$, B. Bennett 00-853, 7 July 2000 (B. Bennett Herbarium, photo DAO); exposed sandy lakeshore, north end of Atlin Lake, $60^{\circ} 01.5^{\prime} \mathrm{N}$ $133^{\circ} 50.4^{\prime} \mathrm{W}$, S. Withers SW01-045, 30 June 2001 (DAO).

The first specimen of this Amphi-Beringian species cited above is the first known from between latitudes $64^{\circ} \mathrm{N}$ and $66^{\circ} \mathrm{N}$ east of the Dempster Highway. The second specimen is an extension of the known range in the Territory of about 200 kilometers southwest of a site east of Haines Junction.

Elymus spicatus (Pursh) Gould - YUKON: common at base of large talus slope, Yukon River, Brittania Creek, 62 52'28"N 138 42'56"W, B. Bennett 02-641, 10 Aug. 2002 (DAO).

Cody (1996) knew this species in the southwest of the Territory and disjunct to the extreme northwest. The specimen cited above is an extension of the known range in the Territory of about 85 kilometers west of longitude $137^{\circ} \mathrm{W}$.

Elymus trachycaulus (Link) Gould ex Shinners ssp. andinus (Scribn. \& Smith) A. \& D. Löve - YuKON: gravel roadside, Top of the World Highway $\mathrm{Km} \mathrm{16}$, 646'6"N 139 38'41"W, Cody \& Cody 38035, 38037, 26 July 2002 (DAO); gravel roadside, Top of the World

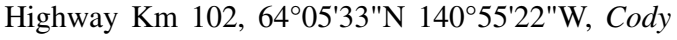
\& Cody 38003, 26 July 2002 (DAO).

The specimens cited above extend the known range in the Territory to the west about 140 kilometers from a site east of the Dempster Highway.

Festuca brachyphylla Schultes \& Schultes f., Shortleaf Fescue - YUKON: Site KPL \#106, 62¹7'38.7"N $137^{\circ} 48^{\prime} 25^{\prime \prime W}$, G. Brunner 578-01, July 2001 (DAO).

The specimen cited above is from a site between sites mapped by Cody (1996) west of Carmacks and adjacent to southern Dempster Highway. 
Festuca richardsonii Hooker - YUKON: beside test plot, $1 \mathrm{~km}$ N of Montague Roadhouse, Km 132 Klondike Highway, 61 $48^{\prime} 35 " \mathrm{~N} 136^{\circ} 7^{\prime} 52^{\prime \prime} \mathrm{W}$, Cody \& Cody 38082, 28 July 2002 (DAO).

This species is frequent in the southern part of the Territory west of longitude $137^{\circ} \mathrm{W}$ and north of latitude $64^{\circ} \mathrm{N}$ but has not previously been found adjacent to the Klondike Highway.

Festuca saximontana Rydb., Rocky Mountain Fescue - YukON: gravel beside road, Alaska Highway $8 \mathrm{~km}$ west of White River, 62 $2^{\circ} 15.6^{\prime \prime} \mathrm{N} 140^{\circ} 38^{\prime} 20.5^{\prime \prime} \mathrm{W}$, Cody \& Cody 37886, 37887, 20 July 2002 (DAO).

The specimens cited above are an extension of the known range in the Territory of about 100 kilometers northwest of a site just northwest of Kluane Lake.

Glyceria striata (Lam.) Hitchc. var. stricta (Scribn.) Fern., Fowl Marina Grass - YukON: moist muddy organic soil, along road from Dalton Post to Wade Lakes, $60^{\circ} 07.765^{\prime} \mathrm{N} 137^{\circ} 04.105^{\prime} \mathrm{W}$, P. Caswell 650,4 Aug. 2002 (DAO).

This plant was considered rare in the Territory by Douglas et al. (1981). Cody (1996) knew it only in the southeast as far west as just west of Watson Lake. The specimen cited above from between the Haines Highway and Kluane National Park is from a site about 450 kilometers to the west. It is however known from British Columbia.

Hordeum brachyantherum Nevski - YUKON: disturbed area in townsite, Big Salmon Village at confluence of Yukon River, $61^{\circ} 53^{\prime} \mathrm{N} 134^{\circ} 55^{\prime} \mathrm{W}$, B. Bennett 02-292, 7 Aug. 2002 (DAO).

Cody (1996) considered this species to be introduced at Dawson City but native and rare at Carcross. Sites in the vicinity of Whitehorse (Cody et al. 2001) were considered to be introduced. The specimen cited above was probably also introduced.

Koeleria macrantha (Ledeb.) Schultes, June Grass YUKON: south aspect-xeric-sage/graminoid-forbs of low compact growth, Site YPC103 near confluence of Pelly and Yukon rivers, 62 $48^{\prime} 16^{\prime \prime} \mathrm{N} 137^{\circ} 19^{\prime} 35.9^{\prime \prime} \mathrm{W}$, G. Brunner 536-01, 3 Aug. 2001 (DAO) (determined by S. Darbyshire); gravel pit just north of the Alaska Highway, Silver City Road, $61^{\circ} 01^{\prime} 22^{\prime \prime N} 138^{\circ} 19^{\prime} 52^{\prime \prime W}$, B. Bennett 01-005, 29 Apr. 2001 (DAO); lower slope south-facing, dry, Five Fingers Coal Mine, Yukon River, $62^{\circ} 12^{\prime} 21^{\prime \prime N} 136^{\circ} 20^{\prime} 10^{\prime \prime W}$, B. Bennett 02-295, 8 Aug. 2002 (DAO).

Douglas et al. (1981) considered this species rare in the Territory. The first specimen cited above was collected just southwest of the Pelly River Ranch at $62^{\circ} 50^{\prime} 20^{\prime \prime} \mathrm{N} 137^{\circ} 11^{\prime} 40^{\prime \prime} \mathrm{W}$ by M. Johansen in 1989 (DAO) (Cody 1996); the second specimen is an extension of about 60 kilometers northwest of a site adjacent to Haines Junction; the third specimen is from a site about 40 kilometers southeast of a site near Minto (Cody 1996).

Poa annua L., Annual Blue Grass - YUKON: vicinity of campground, Rancheria, at mile 710 Alaska Highway $\left(60^{\circ} 05^{\prime} \mathrm{N} 130^{\circ} 36^{\prime} \mathrm{W}\right)$, S. L. Welsh \& G. Moore 7539 , 29 June 1968 (AKA, photo DAO) (determined by R. J. Soreng).
Cody (1996) knew this introduced species from only five sites in the Territory. The specimen cited above is about 100 kilometers west of a site adjacent to the southern Canol Road.

Poa interior Rydb. (P. nemoralis sensu Cody 1996) YUKON: in subalpine meadow, Onion Lake, ca. $46 \mathrm{mi}$ S of Haines Junction, G. W. \& G. G. Douglas 7089, 12 Aug. 1973 (AKA, photo DAO) (determined by R. J. Soreng); common on steep, open, west-facing prairie slopes, Conglomerate Mountain on Dawson-Whitehorse road, $61^{\circ} 38^{\prime} \mathrm{N} 135^{\circ} 53^{\prime} \mathrm{W}$, Calder \& Gillett 25770, 22 June 1960 (DAO); common on south-facing, prairie slope with scattered aspen, Mile 30 on road to Dawson from Stewart Crossing, $63^{\circ} 33^{\prime} \mathrm{N} 137^{\circ} 25^{\prime} \mathrm{W}$, Calder \& Gillett 25037, 4 June 1960 (DAO); grown on open southern slope, Pelly Ranch (ca. 62 $49^{\circ} \mathrm{N}$ $\left.136^{\circ} 34^{\prime} \mathrm{W}\right)$, J. Y. Tsukamoto s.n., 23 July 1960 (DAO); silt bluff, south-facing, on Porcupine River, $1.5 \mathrm{~km}$ upstream from junction between Rat Indian Creek and Porcupine River, $67^{\circ} 34^{\prime} \mathrm{N} 138^{\circ} 21^{\prime} \mathrm{W}$ L. Cwyner 977, 22 July 1976 (DAO) (determined by M. Barkworth); dry open exposed gravel ridge overlooking delta, west side of river on ridge campsite, Lower Blow River Delta, $69^{\circ} 53^{\prime} \mathrm{N} 137^{\circ} 10^{\prime} \mathrm{W}$, H. L. Dickson \& D. L. Allen 5324, 26 July 1982 (DAO); open meadowabandoned beaver pond, Deadman Creek, $60^{\circ} 20.2^{\prime} \mathrm{N}$ $133^{\circ} 03.5^{\prime} \mathrm{W}$, S. Withers SW01-126, 16 July 2001 (DAO) (determined by S. Darbyshire).

Yukon specimens previously mapped as Poa nemoralis by Cody (1996) have been revised to $P$. interior. In addition, the specimens cited above which were inadvertently missed have now been mapped. (See new map Figure 1).

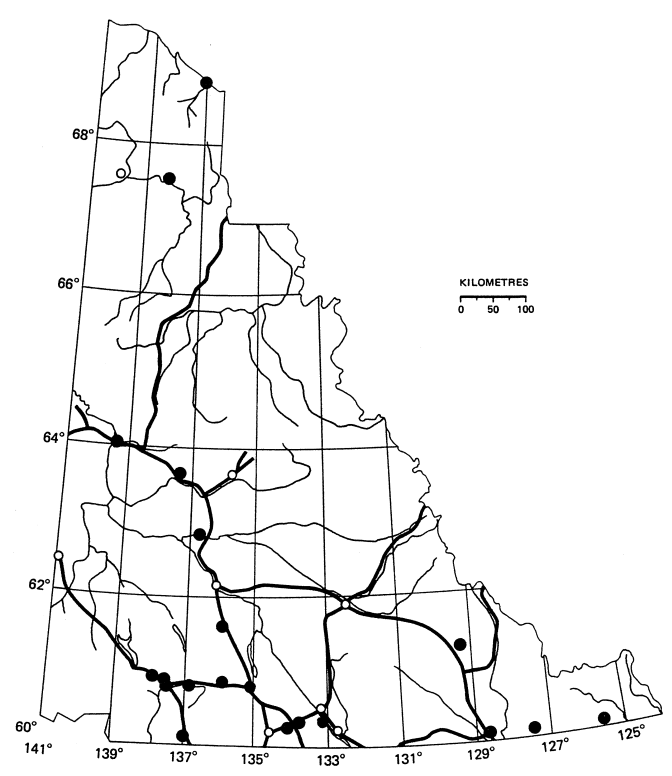

Poa interior

FIGURE 1. New distribution map for Poa interior in the Yukon Territory. 
Poa leptocoma Trin. - YUKON: steep gravelly slope adjacent to Alaska Highway $3 \mathrm{~km}$ east of Snag Junction, $62^{\circ} 12^{\prime} 42.3^{\prime \prime} \mathrm{N} 140^{\circ} 41^{\prime} 33.1 " \mathrm{~W}$, Cody \& Cody 37863, 20 July 2002 (DAO).

The specimen cited above is an extension of the known range in the Territory of about 175 kilometers northwest of a site in Kluane National Park.

Poa secunda Presl, Sandberg Bluegrass - Yukon: commonly found growing on the base of the bluff and occasionally on midslope, Minto Bluff, $62^{\circ} 36^{\prime} 18^{\prime \prime} \mathrm{N}$ 136 $51^{\prime} 06^{\prime W}$, B. Bennett 02-013, 9 June 2002 (DAO).

The specimen cited above is an extension of about 175 kilometers northwest of a site north of Whitehorse (Cody 1996). To the north the only other site in the Territory is in the vicinity of Dawson City.

Puccinellia interior Th. Sor. - Yukon: gravel roadside, Top of the World Highway Km 102, 64 $05^{\prime} 33^{\prime \prime} \mathrm{N}$ $140^{\circ} 55^{\prime} 22^{\prime \prime W}$, Cody \& Cody 38002, 26 July 2002 (DAO).

The specimen cited above is an extension of the known range in the Territory (Cody 1996) of about 75 kilometers west from the vicinity of Dawson City.

Setaria viridis (L.) Beauv., Green Bristlegrass (Figure 2) - YuKON: in crack at edge of Extra Foods parking lot, downtown Whitehorse, B. Bennett 98-437, 14 Oct. 1988 (B. Bennett Herbarium, photo DAO).

The specimen cited above is a new introduction to the Flora of the Yukon Territory (Cody 1996). This species which is introduced from Eurasia is known across Canada from Newfoundland to British Columbia and has been found at Fort Simpson in the Northwest Territories. The genus Setaria can be separated from the genus Panicum as follows:

A. Spikelet surrounded by 1-many distinct or more or less connate bristles, these

forming an involucre .................Setaria

B. Spikelet not subtended by bristles

Panicum

Stipa comata Trin. \& Rupr., Needle-and-thread YUKON: $45^{\circ}$ silty sand south-facing slope with Artemesia frigida and Calamagrostis purpurascens, Dutch Bluff, Yukon River, $61^{\circ} 55^{\prime} \mathrm{N} 135^{\circ} 03.99^{\prime} \mathrm{W}$, B. Bennett 02-289, 7 Aug. 2002 (DAO).

Cody (1996) knew this species in the Territory from only four sites south of $63^{\circ} \mathrm{N}$. Cody et al. (2003) added an additional site just east of Haines Junction. The specimen cited above is from a site about 60 kilometers southeast of Carmacks.

Stipa nelsonii Scribn. ssp. dorei Barkworth \& Maze - YUKON: treeless rocky slope overlooking lake, Snafu Lake Camp Site, $60^{\circ} 08^{\prime} 10^{\prime \prime N} 133^{\circ} 48^{\prime} 23.6^{\prime \prime}$, Cody \& Cody 37567, 28 July 2001 (DAO); open area adjacent to Populus tremuloides woodland overlooking lake, $7 \mathrm{~km}$ east of Tagish Bridge, $60^{\circ} 19^{\prime} 5^{\prime \prime} \mathrm{N}$ $134^{\circ} 10^{\prime} 17^{\prime \prime W}$, Cody \& Cody 37938, 23 July 2002 (DAO).

Cody (1996) knew this species from only six sites in the Territory north to about latitude $61^{\circ} \mathrm{N}$. Cody et al. (2001) added an additional site in the vicinity of the Carcross Dunes. The specimens cited above are from east and southeast of the Carcross Dunes site.

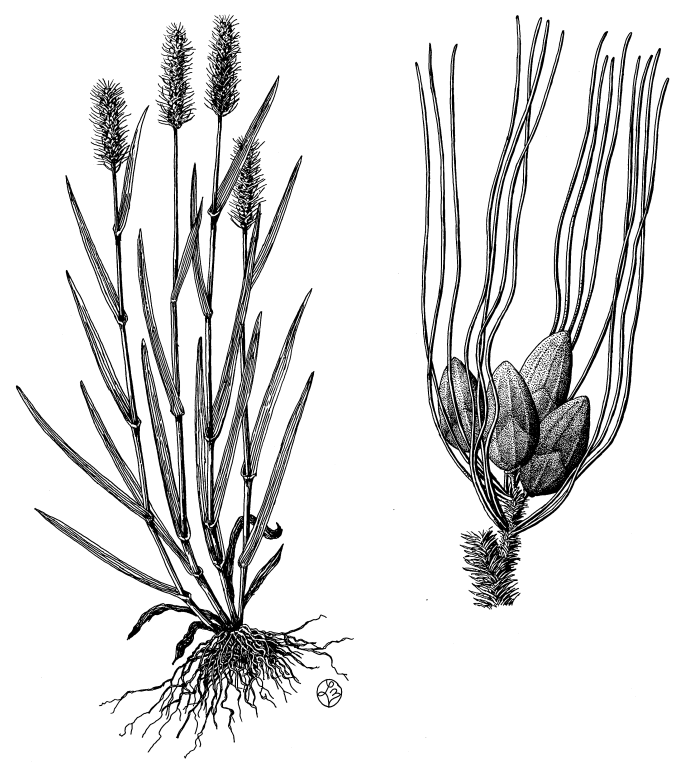

FIGURE 2. Setaria viridis, Green Bristlegrass (drawn by Lee Mennell).

Stipa richardsonii Link (Achnatherum richardsonii (Link) Barkw.), Spreading Needlegrass - YUKON: on steep slope found on lower and mid-slope with Arabis, Arctostaphylos uva-ursi, Festuca saximontana and Poa, hill across Tagish Road from Crag Lake, $60^{\circ} 15^{\prime} 30^{\prime \prime} \mathrm{N}$ $134^{\circ} 28^{\prime} 53 " \mathrm{~W}$, B. Bennett 01-008, 19 May 2001 (DAO); summit of hill behind Carcross Cutoff, south-facing, pine forest Cowley Creek, $60^{\circ} 35.66^{\prime} \mathrm{N} 134^{\circ} 52.96^{\prime} \mathrm{W}$, B. Bennett 99-300, 6 Aug. 1999 (DAO).

Douglas et al. (1981) knew this rare species in the Territory from only one locality from adjacent to the Alaska Highway just east of the Atlin Road junction (Calder \& Gillett 26477, DAO). Cody (1996) mapped three additional sites in the vicinity of Whitehorse. The first specimen cited above is the southernmost yet found in the Territory.

Vahlodea atropurpurea (Wahlenb.) Fries, Mountain Hairgrass - YUKON: Site YPN 120, 6306'39.8"N 13320'15"W, G. Brunner 568-01, 6 Aug. 2001 (DAO).

Cody (1996) knew this taxon from only six localities: adjacent to the North Canol Road, adjacent to the South Macmillan River and near Bennett Lake. Additional sites have since been found east of the Canol Road (Cody et al. 1998 and 2000). The specimen cited above is from a site about 50 kilometers northeast of the Macmillan River site.

\section{CYPERACEAE}

Carex albo-nigra Mack., Two-toned Sedge - YUKON: Volcano Mountain, $62^{\circ} 55^{\prime} \mathrm{N} 137^{\circ} 23^{\prime} \mathrm{W}$, G. Brunner 521-01, 3 Aug. 2001 (DAO); moist scree with organic component on north-facing slope, Vulcan Mountain, Kluane National Park, $60^{\circ} 54.712^{\prime} \mathrm{N} 138^{\circ} 29.484^{\prime} \mathrm{W}, P$. 
Caswell 527, 15 July 2002 (DAO); moist organic soil on southwest facing slope on old semi-abandoned road north of Donjek River bridge, $61^{\circ} 42.209^{\prime} \mathrm{N}$ $139^{\circ} 48.376^{\prime} \mathrm{W}$, P. Caswell 196, 25 June 2002 (DAO).

Cody (1996) knew this rare species in the Territory from seven localities south of latitude $63^{\circ} \mathrm{N}$, three of which were in Kluane National Park. The first specimen cited above is the northernmost yet found in the Territory. Cody et al. (2000) added another site south of Ross River and Cody et al. (2001) another site in the extreme southeast.

Carex athrostachya Olney - YUKON: moist soil by lake, Five Mile Lake Campground, $5 \mathrm{~km} \mathrm{~N}$ of Mayo, $63^{\circ} 39^{\prime} 11.1^{\prime \prime N} 135^{\circ} 53^{\prime} 14.2^{\prime \prime} \mathrm{W}$, Cody \& Cody 37641, 1 Aug. 2001 (DAO).

Douglas et al. (1981) considered this species rare in the Territory on the basis of a specimen collected by R. T. Porsild on the shores of a small bog pond in the vicinity of Mayo, $63^{\circ} 37^{\prime} \mathrm{N} 135^{\circ} 55^{\prime} \mathrm{W}$, on 12 May 1967 (Porsild 1975). The specimen cited above from nearby is only the second yet found in the Territory.

Carex atrosquama Mack. - YUKON: steep gravelly slope adjacent to the Alaska Highway $3 \mathrm{~km}$ east of Snag Junction, $62^{\circ} 12^{\prime} 42.3^{\prime \prime N} 140^{\circ} 41^{\prime} 33.1^{\prime \prime W}$, Cody \& Cody 37861, 20 July 2002 (DAO); cleared gravel by highway, Top of the World Highway Km 92, 646'6'"N 140 46'47"W, Cody \& Cody 38024, 26 July 2002 (DAO).

The first specimen cited above is an extension of the known range in the Territory about 190 kilometers northwest from the south end of Kluane Lake (Cody 1996) and the second specimen is an extension of the known range of about 100 kilometers west of the Dempster Highway.

Carex capillaris L. ssp. chlorostachys (Steven) Löve et al. - YUKON: Klondike River near mouth of Little Klondike, $64^{\circ} 02^{\prime} 00^{\prime \prime} \mathrm{N} 137^{\circ} 41^{\prime} 30^{\prime \prime} \mathrm{W}$, G. Brunner 440, 3 July 2001 (DAO).

The specimen cited above is the first known to Cody (1996) between latitudes $64^{\circ} \mathrm{N}$ and $66^{\circ} \mathrm{N}$ east of the Dempster Highway. It is an extension of about 60 kilometers northeast of a site southwest of the south end of the Dempster Highway.

Carex crawfordii Fern. - YukON: sandy lake shore, Kusawa Lake, $60^{\circ} 34^{\prime} 59.2^{\prime \prime} \mathrm{N} 136^{\circ} 08^{\prime} 26.5^{\prime \prime W}, W . J$. Cody 37718, 13 July 2002 (DAO); meadow adjacent to RCMP foundation, Fort Selkirk, 62 $466^{\prime} 34.4^{\prime \prime N}$ $137^{\circ} 23^{\prime} 35.9^{\prime \prime W}$, Cody \& Kennedy 37749A, 16 July 2002 (DAO).

This species was considered rare in the Territory by Douglas et al. (1981). The specimen from south of Whitehorse cited above is an extension of the known range in the Territory of about 250 kilometers south of a site mapped by Cody (1996) from adjacent to the Pelly River. The second specimen is from about 85 kilometers west of a site adjacent to the Pelly River.

Carex eleusinoides Turcz. - YUKON: moist organic soil with pumice component, down old road west of Alaska Highway north of Donjek River bridge, $61^{\circ} 42.209^{\prime} \mathrm{N} 139^{\circ} 48.376^{\prime} \mathrm{W}$, P. Caswell 205, 2 June 2002 (DAO); gravelly silt near water line, Klondike River, $64^{\circ} 01^{\prime} \mathrm{N} 137^{\circ} 51^{\prime} \mathrm{W}$, G. Brunner 546, 8 July
2001 (DAO); approximately 2 miles downstream from O'Brian Creek on Klondike River, 64ㅇ' $01^{\prime} 46^{\prime \prime} \mathrm{N}$ $38^{\circ} 01^{\prime} 00^{\prime W}, \mathrm{G}$. Brunner 547, 15 July 2001 (DAO).

This species was considered rare in the Territory by Douglas et al. (1981). The first specimen cited above is an extension of the range known to Cody (1996) of about 50 kilometers northwest of the north end of Kluane Lake. The second and third specimens are the first known between latitudes $64^{\circ} \mathrm{N}$ and $66^{\circ} \mathrm{N}$ east of the Dempster Highway and are an extension of about 45 kilometers northeast of a site south of the south end of the Dempster Highway.

Carex foenea Willd. - YukON: Halfway between Orderly House and Robert Luke Cabin, 62 $466^{\prime} 34.4^{\prime \prime} \mathrm{N}$ 137²3'35.9"W, Cody \& Kennedy 37773, 17 July 2002 (DAO).

Douglas et al. (1981) considered this species rare in the Territory. Cody (1996) knew it only from three sites, two of which were in the vicinity of Pelly Crossing. The specimen cited above came from the same area. Cody et al. (1998) reported an additional site in the vicinity of Beaver Ridge/ Larsen Creek.

Carex limosa L. - Yukon: Sphagnum bog, $64^{\circ} 02^{\prime} \mathrm{N}$ $137^{\circ} 41^{\prime} \mathrm{W}$, G. Brunner 441, 3 July 2001 (DAO).

The specimen cited above is only the second known between latitudes $64^{\circ} \mathrm{N}$ and $66^{\circ} \mathrm{N}$ east of the Dempster Highway (Cody 1996).

Carex loliacea L. - Yukon: damp silty ground, forest Picea mariana, Poa glauca, Alnus incana, Salix sp., north side of Klondike River near Parker Creek, $64^{\circ} 01^{\prime} \mathrm{N} 137^{\circ} 51^{\prime} \mathrm{W}$, G. Brunner 592, 9 July 2001 (DAO); spring alongside road, gravelly, Big Gold Creek/60 Mile River Valley, $64^{\circ} 01^{\prime} \mathrm{N} 140^{\circ} 42^{\prime} \mathrm{W}, G$. Brunner 116, 23 July 1991 (DAO).

Cody (1996) considered this species uncommon in the Territory although mapped north to the Porcupine River. The specimens cited above are about equally distant east and west of Dawson City.

Carex obtusata Lilj., Blunt Sedge - YukON: British Mountains, $69^{\circ} 26^{\prime} \mathrm{N} 140^{\circ} 07^{\prime} \mathrm{W}$, A. Martell 625,12 July 1979 (DAO); steep south-facing bluffs along Klondike River, 1 mile north of $64^{\circ} 02^{\prime} 00^{\prime \prime} \mathrm{N} 137^{\circ} 41^{\prime} 30^{\prime \prime} \mathrm{W}, G$. Brunner 432, 2 June 2001 (DAO).

The first specimen cited above is the northernmost yet found in the Territory (Cody 1996). It is an extension of the known range of about 80 kilometers northwest from sites adjacent to the Babbage River. The second specimen cited above is an extension of the known range in the Territory of about 75 kilometers southeast of a site at Sheep Mountain adjacent to the Dempster Highway (Kojima and Brooke 1985).

Carex pachystachya Cham. - Yukon: open meadow, abandoned beaver pond, Deadman Creek, S. Withers SW01-117, 16 July 2002 (B. Bennett Herbarium, photo DAO) (determined by A. A. Reznicek).

This species was not included in The Rare Vascular Plants of the Yukon (Douglas et al. 1981) because it was widespread in Canada. Cody (1996) knew it from only two localities in the extreme southern Yukon. The specimen cited above is from a site about 25 kilometers south southeast of Whitehorse. 
Carex pellita Muhl. ex Willd. - Yukon: silty river bank with Carex utriculata, C. aquatilis, and Juncus alpinoarticulatus, Selwyn, Yukon River, 62 $48^{\circ} 06^{\prime \prime N}$ $138^{\circ} 15^{\prime} 29^{\prime \prime W}$, B. Bennett 02-293, 9 Aug. 2002 (DAO); silty mud at edge of river at high water line with Juncus alpinoarticulatus, Brittania Creek, Yukon River, $62^{\circ} 52^{\prime} 28^{\prime \prime} \mathrm{N} 138^{\circ} 42^{\prime} 52^{\prime \prime} \mathrm{W}$, B. Bennett 02-671, 10 Aug. 2002 (DAO); silty mud at edge of river at high water line with Juncus alpinoarticulatus, Kirkman Creek, Yukon River, 62 59'21"N 139 23'07"W, B. Bennett 02-675, 10 Aug. 2002 (DAO); river bank in area frequently scoured by river ice, confluence of 12 Mile River, Yukon River, $64^{\circ} 15^{\prime} 11^{\prime \prime N} 139^{\circ} 43^{\prime} 18^{\prime \prime} \mathrm{W}$, B. Bennett 02-806, 23 Aug. 2002 (DAO); deeply rooted, edge of river in silty sand bank, Yukon River, 643'ㄹ' $28^{\prime \prime N} 140^{\circ} 38^{\prime} 24^{\prime \prime W}$, B. Bennett 02-807, 24 Aug. 2002 (DAO).

Cody et al. (2000) reported this plant as a rare species in the Territory based on a specimen from a site below Rink Rapids adjacent to the Yukon River. An additional site was reported from Ear Lake, Whitehorse (Cody et al. 2002). The five sites reported above extend the known range in the Territory about 275 kilometers northwest of the Rink Rapids. Bruce Bennett has found that Carex pellita is a common species on the Yukon River between Pink Rapids and White River, less common but can be found downstream and eventually being replaced by $C$. saxatilis.

Carex petasata Dewey - YuKon: east slope adjacent to Alaska Highway ca. $3 \mathrm{~km} \mathrm{~W}$ of Enger Creek, $62^{\circ} 19^{\prime} 12.05^{\prime \prime N} 140^{\circ} 49^{\prime} 19.9^{\prime \prime W}$, Cody \& Cody 37511, 25 July 2001 (DAO); open, abandoned mine road surface, Viceroy Mine - Big Rock Zone, $64^{\circ} 02^{\prime} \mathrm{N}$ $138^{\circ} 17.9^{\prime \prime W}, S$. Withers SW01-057, 3 July 2002 (DAO).

The first specimen cited above is an extension of the known range in the Territory (Cody 1996) of about 215 kilometers west of a site west of Carmacks and 245 kilometers northwest of a site adjacent to Haines Junction. The second specimen cited above is at the northern limit in the Territory about 50 kilometers east of a site in the vicinity of Dawson City.

Carex praegracilis Boott - YUKON: meadow adjacent to RCMP foundation, Fort Selkirk, 62 $466^{\prime} 34.4^{\prime \prime N}$ $137^{\circ} 23^{\prime} 35.9^{\prime \prime W}$, Cody \& Kennedy 37770B, 17 July 2002 (DAO); sandy lake shore, Kusawa Lake, $60^{\circ} 34^{\prime} 59.2^{\prime \prime} \mathrm{N} 135^{\circ} 08^{\prime} 26.5^{\prime \prime W}$, W. J. Cody 37717, 13 July 2002 (DAO).

Douglas et al. (1981) knew this rare species in the Territory from only three localities: Mackintosh, Whitehorse and Carcross. Cody (1996) knew it from 11 sites in the Territory, most of which were south of latitude $61^{\circ} 15^{\prime} \mathrm{N}$. The second specimen cited above is a slight extension of range south of Whitehorse.

Carex rossii R. Br., Ross' Sedge - YukON: decomposed bedrock, South Fork bluffs, Klondike River, $64^{\circ} 01^{\prime} \mathrm{N} 138^{\circ} 9^{\prime} \mathrm{W}, \mathrm{G}$. Brunner 446-01, 14 July 2001 (DAO); steep south-facing bluffs along Klondike River 1 mile north of $64^{\circ} 02^{\prime} \mathrm{N} 137^{\circ} 41^{\prime} 30^{\prime \prime} \mathrm{W}$, G. Brunner 433, 2 June 2001 (DAO).

The specimens cited above are only the third and fourth collections known from north of latitude $64^{\circ} \mathrm{N}$ (Cody 1996) which are from about 80 kilometers east of a site adjacent to Dawson. To the south, the nearest known site is adjacent to the northern South Canol Road about 300 kilometers to the southeast.

Carex stylosa C. A. Mey. - Cody et al. (2000) reported this species which is rare in the Yukon Territory from the Arctic Coast.

The specimen on which it was based (Hoefs \& Smitts 93-37) was misidentified and the range extension should be deleted. There was also an error in the citation where the latitude should have been $69^{\circ} 23^{\prime} \mathrm{N}$ not $60^{\circ} 29^{\prime} \mathrm{N}$

Carex supina Wahl. ssp. spaniocarpa (Steud.) Hultén - YukON: Steep south-facing bluffs along Klondike River 1 mile north of $64^{\circ} 02^{\prime} \mathrm{N} 137^{\circ} 41^{\prime} 30^{\prime \prime} \mathrm{W}$, G. Brunner 434, 2 June 2001 (DAO).

The specimen cited above is the first known in the Territory north of $64^{\circ} \mathrm{N}$ east of the Dempster Highway. The nearest known site is about 75 kilometers to the northwest cited by Kojima \& Brooke (1985).

Carex sychnocephala Carey - YukON: damp, fine gravel with organic component, at base of highway embankment, Alaska Highway just north of Copper Joe Creek, $61^{\circ} 19.814^{\prime} \mathrm{N} 138^{\circ} 56.805^{\prime} \mathrm{W}$, P. Caswell 570, 21 July 2002 (DAO).

Douglas et al. (1981) considered this species rare in the Territory. The specimen cited above is an extension of the range known to Cody (1996) of about 175 kilometers northwest by west of a site west of Whitehorse.

Carex viridula Michx. - YUKON: on moist shoreline of Nares Lake south of Carcross, $60^{\circ} 9^{\prime} 20^{\prime \prime} \mathrm{N}$ 13440'10"W, W. J. Cody 38318, 1 Aug. 2001 (DAO).

This species was considered rare in the Territory by Douglas et al. (1981). The specimen cited above is an extension of the known range to Cody (1996) of about 80 kilometers south of Whitehorse.

Eleocharis uniglumis (Link) Schult. - YUKON: open wet area in old road, adjacent to the Alaska Highway, $61^{\circ} 42.209^{\prime} \mathrm{N} 139^{\circ} 48.376^{\prime} \mathrm{W}$, P. Caswell 204, 25 June 2002 (DAO); in wet moss by lake shore, Fish Lake, $60^{\circ} 46^{\prime} 3.3^{\prime \prime N} 135^{\circ} 03^{\prime} 13 " W$, W. J. Cody 38246, 2 Aug. 2002 (DAO).

The species was considered rare in the Territory by Douglas et al. (1981). The first specimen cited above is an extension of the known range to Cody (1996) of about 150 kilometers northwest of a site northwest of Haines Junction and the second specimen is from a site just south of Whitehorse.

Eriophorum brachyantherum Trautv., Short-anthered Cotton-grass - YUKON: Vuntut National Park, vicinity of Snowdrift Camp, $68^{\circ} 21.4^{\prime} \mathrm{N} 139^{\circ} 13.1^{\prime} \mathrm{W}$, P. Caswell PPC-2000-Y-070, 21 June 2000 (DAO).

The specimen cited above is the northernmost yet found in the Territory (Cody 1996). It is an extension of about 100 kilometers north from sites adjacent to the Porcupine River.

Kobresia simpliciuscula (Wahlenb.) Mack., Simple Kobresia - YUKON: along road track through Picea glauca forest, Minto RV Campground, $62^{\circ} 35^{\prime} \mathrm{N}$ 136 51'W, Cody \& Cody 37678, 6 Aug. 2001 (DAO). 
The nearest site in the Territory (Cody 1996) to the specimen cited above is about 130 kilometers to the southeast adjacent to the Klondike Highway.

Scirpus rollandii Fern. - YUKON: moist organic soil, side road west of Alaska Highway, north of Donjek River bridge, $61^{\circ} 42.209^{\prime} \mathrm{N} 139^{\circ} 48.376^{\prime} \mathrm{W}$, P. Caswell 202, 25 June 2002 (DAO).

Cody (1996) knew this species in the southwest of the Territory where he considered it rare. The specimen cited above is an extension of the known range of about 100 kilometers northwest of southern Kluane Lake.

\section{JUNCACEAE}

Juncus bufonius L. s.l., Toad Rush - YUKON: mud bar, Dezadeash River below Haines Junction, Kluane National Park, $60^{\circ} 45.545^{\prime} \mathrm{N} 137^{\circ} 34.470^{\prime} \mathrm{W}$, P. Caswell 791, 16 Aug. 2002 (DAO).

The specimen cited above is new to Kluane National Park and is a range extension of about 290 kilometers to the south of a site mapped by Cody (1996) and a site east of Johnson's Crossing reported by Cody et al. (2001).

Juncus filiformis L. - YUKON: in muck by small lake adjacent to the Alaska Highway, 60 51'01"N 135'46'0.5"W, Cody \& Cody 38185, 1 Aug. 2002 (DAO).

The specimen cited above which is from a site about 75 kilometers west of Whitehorse is the westernmost yet found adjacent to the Alaska Highway.

Luzula arcuata (Wahlenb.) Sw. ssp. unalaschkensis (Buch) Hultén - gravel beside road and steep slope, Alaska Highway $\mathrm{Km} 1918,62^{\circ} 16^{\prime} 26.1^{\prime \prime N} 140^{\circ} 45^{\prime} 6.7^{\prime \prime}$, Cody \& Cody 37851, 20 July 2002 (DAO).

The specimen cited above is an extension of the known range in the Territory (Cody 1996) of about 215 kilometers northwest of a site northwest of Haines Junction.

\section{LILIACEAE}

Allium schoenoprasum L. ssp. sibiricum (L.) Celak, Wild Onion - YUKON: Herschel Island, $69^{\circ} 35^{\prime} \mathrm{N}$ $139^{\circ} 05^{\prime} \mathrm{W}$, C. E. Kennedy s.n., 1 July 1985 (Environment Yukon Herbarium, photo DAO).

The nearest site known to Cody (1996) was adjacent to the Firth River at $69^{\circ} 13^{\prime} \mathrm{N} 139^{\circ} 35^{\prime} \mathrm{W}$, about 30 kilometers southwest of the Herschel Island site.

Maianthemum canadense Desf. ssp. interius (Fern.) A. \& D. Löve, Wild Lily-of-the-Valley - YuKON: common in understory in the riparian white spruce poplar zone, Contact Creek, 6000'00"N 12743'44"W, B. Bennett 01-025, 25 June 2001 (DAO).

Cody $(1994,1996)$ suggested that this taxon should be looked for in the Territory and Cody et al. $(1998,2000)$ reported it from the extreme southeast. The specimen cited above is an extension of the known range of about 80 kilometers southwest from a site adjacent to the Beaver River hotspring.

Tofieldia coccinea Richards., Northern False Asphodel - YUKON: south aspect-xeric-graminoid/forb/lichen meadow, Volcano Mountain, 62 $55^{\prime} \mathrm{N} 137^{\circ} 23^{\prime} \mathrm{W}, G$. Brunner 521a-01, 3 Aug. 2001 (Environment Yukon, photo DAO).
The specimen cited above is from the first known site between latitudes $62^{\circ} \mathrm{N}$ and $64^{\circ} \mathrm{N}$. The nearest site to the north is about 175 kilometers to a site adjacent to the Dempster Highway and to the southwest about 190 kilometers adjacent to the Alaska Highway.

\section{IRIDACEAE}

Iris setosa Pall. ssp. interior (Anders.) Hultén, Wild Iris - YUKON: at high water level, confluence of 12 Mile River and Yukon River, 64¹5'11"N 139 $43^{\prime} 18^{\prime \prime} \mathrm{W}, B$. Bennett 02-743, 23 Aug. 2002 (DAO).

Cody (1996) knew this rare species in the Territory from only three locations, two from near the western end of the Alaska Highway and one from adjacent to the Takhini River west of Whitehorse. The specimen cited above is an extension of the known range of about 225 kilometers to the north of the sites near the Alaska border. Only four plants were observed.

\section{ORCHIDACEAE}

Spiranthes romanzoffiana Cham. \& Schlecht., Hooded Ladies'-tresses - YUKON: tussocks near bog, east of Haines Highway, $60^{\circ} 08.570^{\prime} \mathrm{N} 136^{\circ} 58.469^{\prime} \mathrm{W}$, P. Caswell 453, 13 July 2002 (DAO).

The specimen cited above is an extension of the known range in the Territory of about 120 kilometers southwest of Whitehorse.

\section{SALICACEAE}

Salix alaxensis (Anderss.) Cov. ssp. longistylis (Rydb.) Hultén - YUKON: beside recreation centre in middle of town, Beaver Creek, 62 $22^{\prime} 56^{\prime \prime} \mathrm{N} 140^{\circ} 52^{\prime} 41^{\prime \prime} \mathrm{W}, B$. Bennett 01-102, 12 June 2001 (DAO).

The specimen cited above is an extension of the known range in the Territory (Cody 1996) of about 140 kilometers northwest of a site near the north end of Kluane Lake.

Salix glauca L. var. acutifolia (Hook.) C. Schneider YuKON: Mt. Merrill, 6006'N 12445'W, G. Brunner, 1994 (DAO).

The specimen cited above is about 90 kilometers east of the easternmost site of Salix glauca sl. mapped by Cody (1996).

Salix pseudomyrsinites (Anderss.) Ball ex Hultén ( $S$. novae-angliae Anderss.) - YUKON: along Bennett Lake just above high water mark, Carcross Dunes, $60^{\circ} 10^{\prime} 30^{\prime \prime N} 134^{\circ} 43^{\prime} 26^{\prime \prime W}$, B. Bennett \& G. Argus 99548, 29 Aug. 1999 (DAO) (determined by G. Argus).

The nearest site of this species known to Cody (1996) is in the vicinity of Whitehorse, about 60 kilometers to the northwest.

Salix rotundifolia Trautv. ssp. dodgeana (Rydb.) Argus - Yukon: Dryas alaskensis tundra, Mount Casca border Monument 97, 65²1'25"N 141 $05^{\circ} 00^{\prime \prime W}, B$. Bennett \& M. B. Cook 02-519, 27 June 2002 (DAO) (determined by G. Argus).

The specimen cited above from adjacent to the Alaska border is from a site about 70 kilometers northwest of the nearest site known to Cody (1996).

\section{URTICACEAE}

Urtica dioica L. ssp. gracilis (Ait.) Selander, Stinging Nettle - YuKON: dwelling mound, Forty Mile Historic Site at the confluence of Forty Mile and 
Yukon rivers, $64^{\circ} 25^{\prime} \mathrm{N} 140^{\circ} 30^{\prime} \mathrm{W}$, C. E. Kennedy 44 , July 2000 (DAO).

The specimen cited above is an extension of the known range in the Territory (Cody 1996) of about 50 kilometers northwest of the vicinity of Dawson City.

\section{POLYGONACEAE}

Polygonum lapathifolium L., Willow Weed, Pale Smartwood - YUKON: wetland Carex fen, uncommon silty mud beside beaver pond, $60^{\circ} 07^{\prime} 00^{\prime \prime} \mathrm{N} 124^{\circ} 15^{\prime} 2 " \mathrm{~W}, B$. Bennett 98-609, 16 June 1998 (DAO).

This species was considered rare in the Territory by Douglas et al. (1981). The specimen cited above is an extension of the known range in the Territory of about 700 kilometers southeast of sites in the vicinity of Carmacks.

Rheum rhabarbarum L. (R. rhaponticum L.) Rhubarb - YUKON: adjacent to garage near machine shop, Fort Selkirk, 62 $46^{\prime} 34.4^{\prime \prime N} 137^{\circ} 23^{\prime} 35.9^{\prime \prime} \mathrm{W}$, Cody \& Kennedy 37799, 17 July 2002 (DAO).

Cody et al. (2001) and (2002) reported Rhubarb growing wild at Silver City and Destruction Bay. The specimen cited above is the third known cited where it was growing wild.

Rumex crispus L., Curled Dock - YUKON: moist shore of small lake between Ross River and Campbell Highway, 61 $58^{\prime} 7 " \mathrm{~N} 132^{\circ} 38^{\prime} 34 " \mathrm{~W}$, Cody \& Cody 37961, 24 July 2002 (DAO).

The specimen cited above is the sixth site in the Territory for this introduced species. Cody (1996) knew it from the vicinity of Dawson City and it has since been reported from just west of Whitehorse, Haines Junction and adjacent to the Alaska Highway near the Alaska border (Cody et al. 2002).

\section{CHENOPODIACEAE}

Atriplex alaskensis S. Watson, (A. patula sensu Cody (1996), A. patula var. alaskensis (S. Wats.) Welsh), Alaskan Orache (Figure 3) - YUKON: alkaline flat, Takhini Salt Flats, $60^{\circ} 51.2^{\prime} \mathrm{N} 135^{\circ} 43.23^{\prime} \mathrm{W}$, Bennett \& Parker 98-431, 2 Sept. 1998 (B. Bennett Herbarium, photo DAO) (determined by P. W. Ball); alkaline flats, between the salt flat and the highway in the area of the fence, Takhini Salt Flats, 60 $51^{\prime} 23^{\prime \prime N} 135^{\circ} 42^{\prime} 55^{\prime \prime} \mathrm{W}$, B. Bennett 01-168, 23 Aug. 2001 (B. Bennett Herbarium, photo DAO); occasional in wet alkaline margin of a brackish slough, Mile 484.5 Alaska Highway west of Whitehorse, R. L. Taylor 4094, 14 July 1959 (DAO); common around clay margins of dried up alkaline pond, east of Haines Junction at Mile 985 Alaska Highway, $60^{\circ} 48^{\prime} \mathrm{N} 136^{\circ} 45^{\prime} \mathrm{W}$, Calder \& Kukkonen 28252, 14 Aug. 1960 (DAO); common around clayey margin of alkaline lake, between Minto and Pelly Crossing on Dawson-Whitehorse road, approximately $62^{\circ} 46^{\prime} \mathrm{N} 136^{\circ} 36^{\prime} \mathrm{W}$, Calder \& Kukkonen 28095, 10 Aug. 1960 (DAO).

Cody (1996) considered the Calder \& Cody specimens as introductions from Europe (A. patula). Atriplex alaskensis should now be added to the Yukon Flora and the list of rare plants of the Territory (Douglas et al. 1981). The Taylor specimen cited above was the basis for the drawing published in the Yukon Flora as A. patula.
Atriplex subspicata (Nutt.) Rydberg - YUKON: grassy area in open alkaline salt ponds, Mayo Road, Dillabough's Grazing Lease, $60^{\circ} 55^{\prime} 54 " \mathrm{~N} 135^{\circ} 10^{\prime} 14 " \mathrm{~W}, B$. Bennett 02-649, 19 Aug. 2002 (DAO).

Cody (1996) knew this species from a single locality adjacent to a saline pond just west of Whitehorse. The specimen cited above from just north of Whitehorse is only the second known from the Territory.

Chenopodium capitatum (L.) Asch., Strawberry-blite - YUKON: disturbed gravelly soil, roadstop, Atlin Road just north of BC border, 60 $00^{\circ} 09^{\prime \prime} \mathrm{N} 133^{\circ} 47^{\prime} 42.1^{\prime \prime} \mathrm{W}$, Cody \& Cody 37546, 28 July 2001 (DAO).

The specimen cited above is an extension of the known range in the Territory (Cody 1996) of about 60 kilometers to the southwest from a site in the vicinity of Johnson's Crossing.

Corispermum ochotense Ignatov var. alaskanum Mosyakin (C. hyssopifolium sensu Cody 1996) YUKON: river bar in loose aluvial sand between Salix exigua and river with Tanacetum bipinnatum, Potentilla anserina and Aster falcatus, Yukon River at confluence of Nester Creek, 64³8'22"N 140 52'52"W, Bennett \& Mulder 02-665, 25 Aug. 2002 (DAO); river bar in loose alluvial sand between Salix exigua and river with Tanacetum bipinnatum, Potentilla anserina and Aster falcatus, Yukon River, 64 ${ }^{\circ} 22^{\prime} 19^{\prime \prime} \mathrm{N}$ $140^{\circ} 26^{\prime} 49 " \mathrm{~W}$, Bennett \& Mulder 02-740, 24 Aug. 2002 (DAO).

The specimens cited above are the first yet found in the Territory.

\section{Portulacaceae}

Claytonia megarrhiza (A. Gray) Parry, Alpine Springbeauty (Figure 3) - YUKON: alpine tundra, three plants seen at base of a long scree slope near a very small stream, northwest side of Wade Mountain, Kluane National Park, $61^{\circ} 18^{\prime} \mathrm{N} 139^{\circ} 33^{\prime} \mathrm{W}$, P. Caswell 236, 28 June 2002 (DAO).

This species, which is new to the Flora of the Yukon Territory (Cody 1996), should be added to the list of rare plants of the Territory (Douglas et al. 1981). Porsild and Cody (1980) knew it from three sites in the Mackenzie Mountains in the Continental Northwest Territories and McJannet et al. (1995) knew it from four sites in that area in the Rare Vascular Plants in the Northwest Territories. To the south Douglas et al. (2002) mapped three sites in the extreme southeast of British Columbia where it was considered rare.

Montia fontana L., Blinks - YUKON: aquatic, growing in the shallows $(10-30 \mathrm{~cm})$ in a backwater slough, Lewes Marsh, $60^{\circ} 34^{\prime} \mathrm{N} 134^{\circ} 35^{\prime} \mathrm{W}$, B. Bennett 001091, 25 June 2000 (DAO) (determined by C. Parker and W. J. Cody).

Cody (1996) knew this rare plant in the Territory only from a single locality on the Arctic Coast where it was collected by Erling Porsild in 1934 (CAN, photo DAO). In addition a second specimen was collected by Cody on Herschel Island in 1999 (Cody et al. 2001). This is a circumpolar, low-arctic species, which was considered rare in the Territory by Douglas et al. (1981). To the east of the location cited above it is known from the southern Mackenzie Mountains in the 


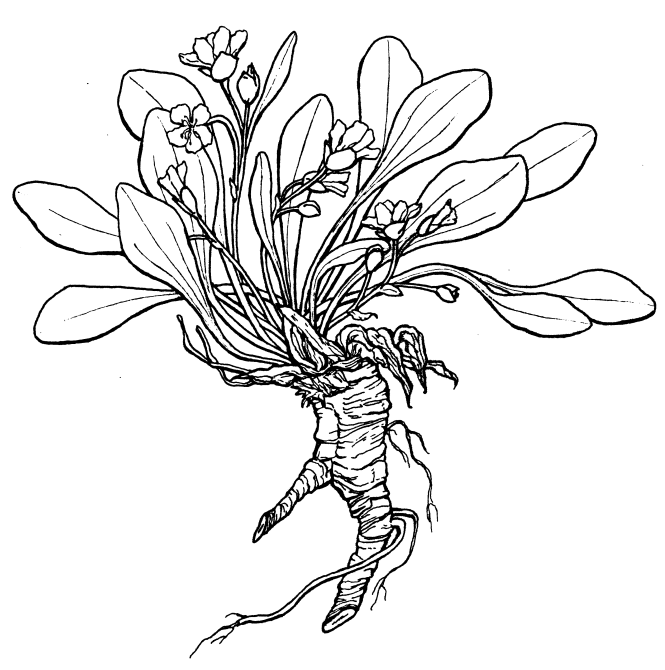

FIGURE 3. Claytonia megarrhiza, Alpine Springbeauty (drawn by Lynne Bartosch).

former District of Mackenzie, and to the west in essentially coastal regions of Alaska and British Columbia.

\section{CARYOPHYLLACEAE}

Cerastium arvense L., Field Chickweed - YuKON: wet roadside ditch, Top of the World Highway Km 100, $64^{\circ} 05 ' 53^{\prime \prime N ~ 14054 ' 43 " W, ~ C o d y ~ \& ~ C o d y ~ 38011, ~} 26$ July 2002 (DAO).

The specimen cited above is an extension of the known range in the Territory (Cody 1996) of about 100 kilometers west of the vicinity of Dawson City.

Minuartia dawsonensis (Britt.) House - YUKON: steep slope by Alaska Highway, $8 \mathrm{~km}$ west of White River, 62 3 '15.6"N 140³8'20.5"W, Cody \& Cody 37880, 20 July 2002.

The specimen cited above is an extension of the known range in the Territory (Cody 1996) of about 125 kilometers northwest of a site adjacent to Kluane Lake.

Minuartia elegans (Cham. \& Schlecht.) Schischk. YUKON: Dryas alaskensis heath, $30^{\circ}$ southwest-facing large talus dolomite boulders, summit of mountain on Canadian side of Mount Casca, 65 21'37"N 14059'34"W, B. Bennett \& M. B. Cook 02-543, 27 June 2002 (B. Bennett Herbarium, photo DAO).

The specimen cited above from adjacent to the Alaska border is an extension of the known range of about 75 kilometers northwest of the nearest site in the Ogilvie Mountains.

Minuartia macrocarpa (Pursh) Ostenf. - YUKON: alpine tundra, spotty occurrence in raised rocky mounds, mountain between Kusawa and JoJo Lake, 60³5'47"N 136¹5'19"W, B. Bennett 97-681, 19 Sept. 1997 (DAO).

The specimen cited above is an extension of the known range in the southwest of the Territory of about 80 kilometers southeast of a site northwest of Haines Junction.
Minuartia yukonensis Hultén - YUKON: coarse gravel and small rocks of a stream's outwash, Upper Joe Creek, Kluane National Park, $61^{\circ} 12.861^{\prime} \mathrm{N} 139^{\circ} 03.863^{\prime} \mathrm{W}$, $P$. Caswell 585, 24 July 2002 (DAO).

The specimen cited above is an extension of the known range in the Territory (Cody 1996) of about 225 kilometers west of a site north of Whitehorse.

Silene involucrata (Cham. \& Schlecht.) Bocquet ssp. tenella (Tolm.) Bocquet - YuKON: meadow between Stone House and river near Fort Selkirk sign, Fort Selkirk, 6246'34.4"N 137²3'35.9"W, Cody \& Kennedy 37805, 17 July 2002 (DAO).

The specimen cited above is from a site between sites in the vicinity of Mayo and south of latitude $62^{\circ}$.

Silene williamsii Britton - YuKON: talus lower slope of southwest-facing bluff, Yukon River, Minto Bluff, $62^{\circ} 37^{\prime} 06^{\prime \prime N ~ 136 ~ 57 ' 41 " W, ~ B . ~ B e n n e t t ~ 02-678, ~} 9$ Aug. 2002 (B. Bennett Herbarium, photo DAO); common on base of slope across from Brittania Creek growing with Artemisia frigida and Calamagrostis purpurascens, Yukon River, 62 52'28"N 138 42'56"W, Bennett 02-443, 10 Aug. 2002 (B. Bennett Herbarium, photo DAO).

This species was considered rare in the Territory by Douglas et al. (1981) on the basis of 3 collections from south and southwest of Dawson City.

Silene vulgaris (Moench) Garcke, Bladder Campion - YUKON: gravelly soil in old field with grass and sweet clover, west of Mayo airport, 633'01.4"N 135'58'20.9"W, Cody \& Cody 37665, 4 Aug. 2001 (DAO).

The specimen cited above of this introduced species in the Territory (Cody 1996) was previously known only from an area just east of Dawson.

Stellaria umbellata Turcz. - YUKON: wet scree cushion in zinc moss, Wade Mountain, Kluane National Park, $61^{\circ} 18.450^{\prime} \mathrm{N} 139^{\circ} 30.921^{\prime} \mathrm{W}$, P. Caswell 354, 7 July 2002 (DAO).

Douglas et al. (1981) considered this species as rare in the Territory. Cody (1996) knew it from only three widely separated sites. The specimen cited above is from a site about 60 kilometers northwest of a previously known site in Kluane National Park.

\section{NyMPHAEACEAE}

Nuphar polysepalum Engelm., Yellow Pond-lily YUKON: shallow water along shore of lake, Tatchun Lake Campground, 62 $17^{\prime} 52.8^{\prime \prime} \mathrm{N}$ 136 08'11.4"W, Cody \& Cody 37626, 30 July 2001 (DAO).

The specimen cited above is an extension of the known range in the Territory (Cody 1996) of about 120 kilometers to the north, south of Mayo.

\section{Ranunculaceae}

Pulsatilla ludoviciana (Nutt.) Heller, Prairie-crocus YUKON: steep grassy slope on ridge northeast of Woodburn Creek, Tintina Trench, Ddhaw Ghro, $63^{\circ} 08^{\prime} \mathrm{N}$ $136^{\circ} 05^{\prime}$ W, C. E. Kennedy 4, 27 July 2001 (DAO). 
The specimen cited above is an extension of the known range in the Territory (Cody 1996) of about 100 kilometers east northeast of a site north of the junction of the Pelly and Yukon rivers.

Ranunculus aquatilis L. var. subrigidus (W. B. Drew) Breitung - YUKON: near South Fork intake, Klondike River on edge of beaver dam in old ditch, $64^{\circ} 0^{\prime} 30^{\prime \prime} \mathrm{N}$ $138^{\circ} 12^{\prime} 00^{\prime \prime W}$, G. Brunner 549, 22 July 2002 (DAO).

The nearest site known to Cody (1996) of this uncommon variety was about 60 kilometers to the north adjacent to the Dempster Highway.

Ranunculus occidentalis Nutt. var. brevistylis Greene, Western Buttercup - YUKON: alpine tundra, valley above treeline, Macmillan Pass, $63^{\circ} 15^{\prime} \mathrm{N} 130^{\circ} 02^{\prime} \mathrm{W}$, J. Basinger s.n., June 1982 (DAO).

Douglas et al. (1981) considered this species rare in the Territory. The specimen cited above is the northernmost yet found in the Territory and is an extension of the known range of about 250 kilometers northeast of a site adjacent to the northern South Canol Road.

\section{PAPAVERACEAE}

Papaver croceum Ledeb. - YUKON: by garbage along trail in Picea glauca, Pinus, Populus tremuloides woodland, Whitehorse, near Hidden Lake, $60^{\circ} 35^{\prime} 00.5^{\prime \prime} \mathrm{N}$ 135 51'00.2"W, Cody \& Cody 37678A, 9 Aug. 2001 (DAO); in gravel beside car parking spot, 11 Chalet Crescent, Whitehorse, 605 $54.7^{\prime \prime} \mathrm{N} 135^{\circ} 10^{\prime} 26.5^{\prime \prime} \mathrm{W}$, W. J. Cody 37711, 12 July 2002 (DAO) (determined by H. Solstad).

This species is a garden escape which has not previously been recorded from the Whitehorse area. In addition Heidi Solstad revised three collections previously determined as Papaver nudicaule (Dawson, Calder \& Billard 3121 (DAO), Halfway Lakes area 15 miles north of Mayo, Calder \& Gillett 4176 (DAO) and Tower Hill, Tagish, R. Rosie 798 (DAO)) to $P$. croceum. P. nudicaule ssp. nudicaule should be replaced by $P$. croceum in the flora (Cody 1996, 2000).

\section{BRASSICACEAE (CRUCIFERAE)}

Alyssum obovatum (C. A. Meyer) Turcz. (A. americanum Greene) - YUKON: $45^{\circ}$ talus southwest-facing slope, Yukon River, $1 \mathrm{~km}$ east of Alaska/Yukon border, $64^{\circ} 41^{\prime} 05^{\prime \prime N} 140^{\circ} 57^{\prime} 30 " \mathrm{~W}$, Bennett \& Mulder 02-666, 25 Aug. 2002 (B. Bennett Herbarium, photo DAO) (determined by G. A. Mulligan).

Douglas et al. (1981) considered this species too widespread to include it in The Rare Vascular Plants of the Yukon. Cody (1996) knew it from only eleven sites north of latitude $62^{\circ} \mathrm{N}$. The specimen cited above is a slight extension of the known range in the Territory about 50 kilometers to the northwest of another site adjacent to the Yukon River.

Arabis caucasica Willd., Wall Rock-Cress (Figure 4) - YUKON: garden escape, Alsek Road, Hayes Property, $10 \mathrm{~km} \mathrm{NW}$ of Haines Junction, $64^{\circ} 47^{\prime} \mathrm{N} 137^{\circ} 41^{\prime} \mathrm{W}$, B. Bennett 01-041, 12 June 2001 (DAO) (determined by G. A. Mulligan). Submitted to B. Bennett by Carolyn Hayes.

This garden escape has not previously been observed in the Yukon Territory.

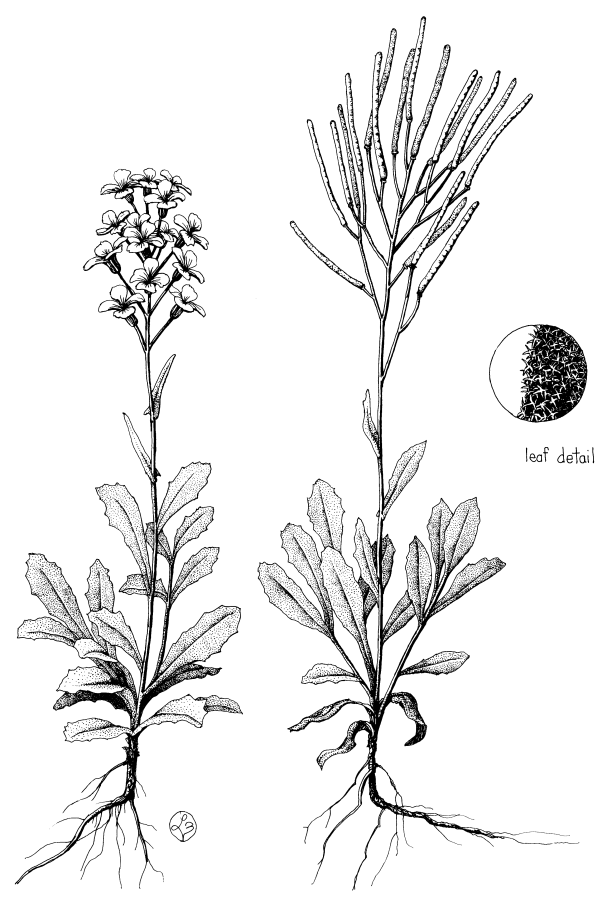

FIGURE 4. Arabis caucasica (drawn by Lee Mennell).

Arabis caucasica can be separated from A. codyi as follows:

A. Garden escape; cauline and caudex leaves with similar dentate to subdentate margins, flowering stems spreading to ascending; petals $6.5 \mathrm{~mm}$ long ................ Aaucasica

B. Native species; cauline and caudex leaves not similarly dentate to subdentate; flowering stems erect; petals more than $10 \mathrm{~mm}$ long .............. codyi

Arabis holboellii Hornem. var. retrofracta (Graham) Rydb. - YuKON: gravel beside road and steep slope, Alaska Highway Km 1918, 62¹6'26.1"N 14045'6.7"W, Cody \& Cody 37855, 20 July 2002 (DAO).

The nearest site adjacent to the Alaska Highway known to Cody (1996) is about 150 kilometers to the southeast in the vicinity of Kluane Lake. There is, however, a site adjacent to a river about 60 kilometers to the east.

Arabis holboellii Hornem. var. secunda (Howell) Jepson - YUKON: adjacent to narrow road through woods leading down to Nares Lake southeast of Carcross, $60^{\circ} 9^{\prime} 20^{\prime \prime} \mathrm{N} 134^{\circ} 40^{\prime} 10^{\prime \prime W}$, Cody \& Cody 37934, 23 July 2002 (DAO) (determined G. A. Mulligan).

Cody (1996) knew this taxon from only four localities in the Territory, west of longitude $135^{\circ}$. Cody (2001) added new sites in the vicinity of Whitehorse and Wolf Lake to the east. The specimen cited above is the southernmost yet found in the Territory. 
Armoracia rusticana (Lam.) Gaert., Mess. \& Scherb. YUKON: Hultén (1941-50) reported this species "A specimen of this plant was collected at Stewart R. July 1898 by Andersson (S). It must have been cultivated or have escaped from cultivation". Hultén (1968) mapped the worldwide distribution of this species with a single dot in the Territory and Welsh (1974) sub Rorippa armorocia (L.) A. S. Hitchc. stated "Cultivated for the root; in southern Alaska and Yukon, persisting; introduced from Europe". Fortunately this species was overlooked by Cody when preparing the Flora of the Yukon Territory (1996); since the Anderson specimen was recently borrowed from the Swedish Museum of Natural History, Stockholm and was revised by Gerald A. Mulligan to Rorippa barbareifolia (DC.) Kitagawa, an amphi-Berigian, nonarctic species which extends across Alaska to central Yukon Territory, the Porcupine River valley, the central Richardson Mountains and the Fort McPherson area south of the Mackenzie Delta.

Brassica rapa L., Bird rape - YUKON: roadside gravel, Alaska Highway, near Kluane Wilderness Camp Km 1791, B. Bennett 01-095, 24 July 2001 (DAO).

The specimen cited above of this introduced species is an extension of the known range in the Territory of about 175 kilometers northwest of a site adjacent to the Haines Highway. It may have resulted from roadside seeding.

Camelina sativa (L.) Cranz, Falseflax (Figure 5) YUKON: disturbed site, Whitehorse Shipyards, $60^{\circ} 43^{\prime} 34^{\prime \prime N} 135^{\circ} 03^{\prime} 12^{\prime \prime W}$, B. Bennett 01-150, 28 Aug.

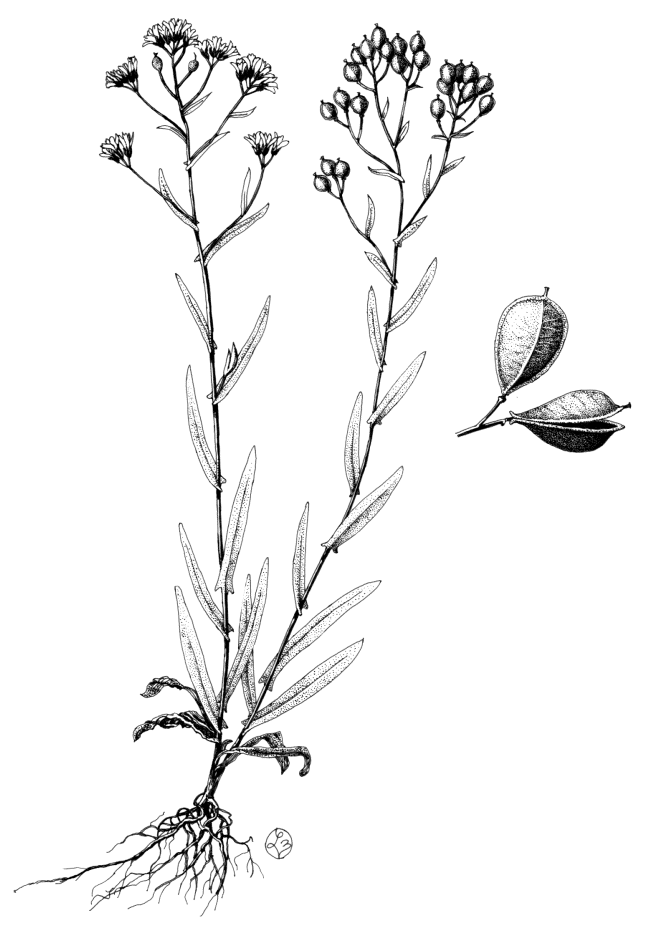

FIGURE 5. Camelina sativa, Falseflax (drawn by Lee Mennell).
2001 (B. Bennett Herbarium, photo DAO) (determined by G. A. Mulligan).

The specimen cited above is new to the Flora of the Yukon Territory (Cody 1996). It is a Eurasian introduction which is known in Canada from New Brunswick to British Columbia and north into southern District of Mackenzie.

The genus Camelina can be separated from the genus Alyssum as follows:

A. Styles usually $2-3 \mathrm{~mm}$ long; silicles oval-elliptic to egg-shaped, usually at least $5 \mathrm{~mm}$ long; seeds numerous; petals often shallowly bilobed; annual Camelina

B. Styles not over $1 \mathrm{~mm}$ long; silicles oval in outline, less than $5 \mathrm{~mm}$ long; petals not bilobed; perennial .............. Alyssum

Capsella bursa-pastoris (L.) Medic., Shepherd's-purse - Yukon: level gravel area, Campbell Highway Km $380,62^{\circ} 02^{\prime} 34.2^{\prime \prime} \mathrm{N} 132^{\circ} 52^{\prime} 02.2^{\prime \prime} \mathrm{W}$, Cody \& Cody 37591, 30 July 2001 (DAO); growing beside Artemisia tilesii by narrow road through woodland, Pelly

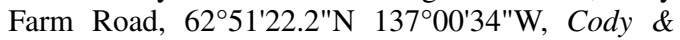
Kennedy 37821B, 17 July 2002 (DAO); gravel, Pickhandle Lake, $63^{\circ} 02^{\prime} 22.2^{\prime \prime} \mathrm{N} 138^{\circ} 23^{\prime} 15.8^{\prime \prime} \mathrm{W}$, Cody \& Cody 37834, 20 July 2002 (DAO).

The first specimen cited above of this introduced species is from a site between two sites adjacent to the Campbell Highway (Cody 1996) in the vicinity of Carmacks. One of sites is 175 kilometers to the west and the other is about 185 kilometers to the southeast. The second and third specimens are from sites between Keno and Carmacks (Cody 1996).

Cardamine bellidifolia L., Alpine Bittercress - YuKON: Herschel Island, $69^{\circ} 35^{\prime} \mathrm{N} 139^{\circ} 05^{\prime} \mathrm{W}$, C. E. Kennedy s.n., 20 July 1985 (DAO).

The nearest sites known to Cody (1996) were from the north coast about 30 kilometers to the west and near the Firth River about 30 kilometers to the southwest.

Descurainia incisa (Engelm. ex A. Gray) Britton var. incisa, Tansy Mustard - YUKON: gravel roadside, rare, Dempster Highway Km 98, 64²' $\mathrm{N} 138^{\circ} 24^{\prime} 46^{\prime \prime W}$, Cody \& Cody 38056, 27 July 2002 (DAO) (determined by G. A. Mulligan).

Cody et al. (2001) reported this species as new to the Territory and Cody et al. (2002) added additional sites adjacent to the Alaska Highway north of latitude $62^{\circ} \mathrm{N}$. The specimen cited above is from the first known site adjacent to the Dempster Highway.

Draba aurea M. Vahl, Golden Draba - YukON: Site KPL 110, 62 ${ }^{\circ} 15^{\prime} 09.6^{\prime \prime N} 137^{\circ} 41^{\prime} 03^{\prime \prime W}$, G. Brunner 591-01, 8 Aug 2001 (Environment Yukon Herbariam, photo DAO) (determined by G. A. Mulligan).

The specimen cited above is the northernmost yet found in the Territory (Cody 1996). It is an extension of the known range of about 50 kilometers from a site south of latitude $62^{\circ} \mathrm{N}$.

Draba corymbosa $\mathrm{R}$. Br. - YUKON: Herschel Island, $69^{\circ} 35^{\prime} \mathrm{N} 139^{\circ} 05^{\prime} \mathrm{W}$, C. E. Kennedy s.n., 10 Aug. 1985 (Environment Yukon Herbarium, photo DAO) (determined by G. A. Mulligan). 
The nearest site known to Cody (1996) was from near the Firth River about 30 kilometers to the southwest.

Draba crassifolia Graham - YUKON: sandy moist soil in eroded area, ridge south of Donjek Glacier, $61^{\circ} 08.277^{\prime} \mathrm{N}$ 139³1.170'W, P. Caswell 403, 8 July 2002 (DAO) (determined by G. A. Mulligan).

The specimen cited above is an extension of the known range in the Territory (Cody 1996) northwest of sites in Kluane National Park.

Draba glabella Pursh - YUKON: steep south-facing bluffs along Klondike River, 1 mile north of $64^{\circ} 02^{\prime} 00^{\prime \prime N} 137^{\circ} 41^{\prime} 30^{\prime \prime W}$, G. Brunner 438, 2 June 2001 (DAO) (determined by G. A. Mulligan).

The specimen cited above is from a site about 70 kilometers east of a site in the vicinity of Dawson City (Cody 1996).

Draba nemorosa L., Wood Whitlow-grass - YUKON: disturbed farm area, Black Sheep airline base, Mayo, $63^{\circ} 35.26^{\prime} \mathrm{N} 135^{\circ} 51.83^{\prime} \mathrm{W}$, B. Bennett 00-1193, 2 July 2000 (DAO) (determined by G. A. Mulligan).

The specimen cited above is an extension of the known range in the Territory (Cody 1996) of about 110 kilometers northeast of a site west of longitude $137^{\circ} \mathrm{W}$ and north of the Pelly River.

Draba ogilviensis Hultén - YUKON: summit of small peak south of Donjek Glacier, Kluane National Park, $61^{\circ} 08.318^{\prime} \mathrm{N} 139^{\circ} 31.132^{\prime} \mathrm{W}$, P. Caswell 392, 8 July 2002 (DAO) (determined by G. A. Mulligan).

Douglas et al. (1981) considered this species rare in the Territory. The specimen cited above is the westernmost yet known in Kluane National Park.

Draba palanderiana Kjellm. - YUKON: dry alpine Dryas heath with Dryas alaskensis, Silene acaulis, Synthyris borealis, Podistera macounii and lichens, summit of mountain, calcareous dolomite talus, $65^{\circ} 21.37^{\prime} \mathrm{N} 140^{\circ} 59.34^{\prime} \mathrm{W}$, B. Bennett 02-523, 27 June 2002 (DAO).

The specimen cited above from adjacent to the Alaska border is an extension of the known range in the Territory of about 60 kilometers to the north of a site mapped by Cody (1996).

Draba porsildii G. A. Mulligan - YUKON: wet scree, Wade Mountain, Kluane National Park, $61^{\circ} 18^{\prime} \mathrm{N}$ 139³3'W, P. Caswell 240, 2 June 2002 (DAO) (determined by G. A. Mulligan).

Douglas et al. (1981) considered this species rare in the Territory on the basis of three specimens from Kluane National Park and one from the South Canol Road southwest of Ross River. Cody (2003) cited a specimen from west of the three sites in Kluane National Park. The specimen cited above is from an additional site in the Park about 70 kilometers north of the last site.

Draba stenoloba Ledeb. - YuKON: Donjek Valley, $61^{\circ} 25.689^{\prime} \mathrm{N} 139^{\circ} 53.074 ' \mathrm{~W}$, R. Maraj s.n., 29 June 2002 (DAO) (determined by G. A. Mulligan).

The specimen cited above is an extension of the known range in the Territory (Cody 1996) of about 90 kilometers northwest of a site in Kluane National Park.
Lepidium densiflorum Schrad. var. densiflorum, Common Pepper-grass - YUKON: roadstop in disturbed gravelly soil, Atlin Road just north of BC border, $60^{\circ} 00^{\prime} 09^{\prime \prime} \mathrm{N} 133^{\circ} 47^{\prime} 42.1^{\prime \prime W}$, Cody \& Cody 37543, 37551, 28 July 2001 (DAO) (determined by G. A. Mulligan).

The specimens cited above are an extension of the known range in the Territory (Cody 1996) of about 125 kilometers southeast of a site just west of Whitehorse.

Lepidium densiflorum Schrad. var. macrocarpum G. A. Mulligan - YUKON: adjacent to Catholic Church, Fort Selkirk, 62 ${ }^{\circ} 46^{\prime} 34.4^{\prime \prime N} 137^{\circ} 23^{\prime} 35.9^{\prime \prime W}$, Cody \& Kennedy 37808A, 17 July 2002 (DAO) (determined by G. A. Mulligan).

Cody et al. (2001) reported this variety, which is probably introduced, new to the Territory from the vicinities of Dawson, Ross River and Pelly Crossing. The specimen cited above is an extension of the known range in the Territory of about 50 kilometers to the west of Pelly Crossing.

Parrya arctica $\mathrm{R}$. Br. - Two specimens, one from Pauline Cove, Herschel Island (Cody 36030) and the other from the Bonnet Plume River (Loewen 99-28-93) were recently revised to $P$. nudicaulis by G. A. Mulligan. These two species can be separated as follows:
A. Stamens linear, 1.5 to
$1.75 \mathrm{~mm}$ long . ............. nudicaulis
B. Stamens oblong, less than
$1.0 \mathrm{~mm}$ long ................. arctica

In addition, Cody (1994) reported P. arctica from Herschel Island on the basis of a specimen collected by P. F. Cooper (433), 9 May 1979 (CAN) as new to the Territory and suggested that it should be added to the list of rare plants (Douglas et al. 1981). This specimen has now been revised to Thlaspi arcticum Porsild by G. A. Mulligan and should be deleted from the flora of Herschel Island and the Yukon Territory.

Rorippa barbareifolia (DC.) Kitagawa - YUKON: Pelly Crossing, 62 51'09"N 136 56'05.2"W, Cody \& Kennedy 37831, 17 July 2002 (DAO) (determined by G. A. Mulligan).

This species was considered rare in the Territory by Douglas et al. (1981). The specimen cited above is the southernmost yet found adjacent to the Alaska Highway.

Sinapis arvensis L., Charlock - YUKON: in a well-tended flower bed, Haines Junction, P. Caswell 311, 5 July 2002 (DAO) (determined by G. A. Mulligan).

The specimen cited above which was the only plant observed in Haines Junction of this introduced species was from only the third site known to Cody (1996) in the Territory.

Subularia aquatica L. ssp. americana Mulligan \& Calder, Awlwort - YUKON: shallows of large pond east of Alaska Highway north of Sulphur Lake, $61^{\circ} 00.435^{\prime} \mathrm{N}$ 138 ${ }^{\circ}$ 12.729'W, P. Caswell 772, 9 Aug. 2002 (DAO) (determined by G. A. Mulligan).

This species was considered rare in the Territory by Douglas et al. (1981). The specimen cited above is an extension of the known range of about 175 kilometers east of a site in the vicinity of Whitehorse (Cody 1996). 
Thlaspi arvense L., Penny Cress - in black muck just inside gate, flats 7 miles east of Tagish Bridge, $60^{\circ} 19^{\prime} 5^{\prime \prime} \mathrm{N} 134^{\circ} 10^{\prime} 17^{\prime \prime W}$, Cody \& Cody 37958, 23 July 2002 (DAO) (determined by G. A. Mulligan).

The specimen cited above is an extension of the known range of this introduced species of about 80 kilometers southeast of the vicinity of Whitehorse.

\section{SAXIFRAGACEAE}

Ribes oxyacanthoides L. ssp. oxyacanthoides - YUKON: meadow adjacent to RCMP foundation, Fort Selkirk, $62^{\circ} 46^{\prime} 34.4^{\prime \prime} \mathrm{N} 137^{\circ} 23^{\prime} 35.9^{\prime \prime W}$, Cody \& Kennedy 37757, 16 July 2002 (DAO).

Although quite frequent in the Territory south of latitude $62^{\circ} \mathrm{N}$, Cody (1996) knew this shrub from only two sites to the north.

Saxifraga caespitosa L. - YUKON: $40^{\circ}$ slope talus dolomite boulders, Mount Casca border Monument 97, $65^{\circ} 21^{\prime} 25^{\prime \prime} \mathrm{N} 141^{\circ} 00^{\prime} 00^{\prime \prime W}$, B. Bennett \& M. Cook 02515A, 27 June 2002 (DAO).

Cody (1996) mapped this species in the Territory from three distinct areas (between latitudes $60^{\circ}$ and $62^{\circ}$, between latitudes $64^{\circ}$ and $66^{\circ}$, and north of latutude $68^{\circ}$. The specimen cited above from adjacent to the Yukon-Alaska border is about 70 kilometers from the sites east and southeast.

Saxifraga eschscholtzii Sternb. - YuKON: dry alpine heath at summit of mountain on Canadian side of

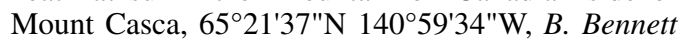
\& M. Cook 02-512, 27 June 2002 (DAO).

Cody (1996) knew this species only from the British Mountains in the extreme northwest of the Territory. The specimen cited above is an extension of the known range in the Territory of about 460 kilometers to the south.

Saxifraga foliolosa $\mathrm{R}$. Br. - YUKON: damp sand of small sandy depression in sedge tundra, ridge south of Donjek Glacier, Kluane National Park, $61^{\circ} 07.383^{\prime} \mathrm{N}$ $139^{\circ} 31.308^{\prime} \mathrm{W}$, P. Caswell 416, 8 July 2002 (DAO).

Douglas et al. (1981) considered this species which was known to Cody (1996) from north of latitude $67^{\circ} \mathrm{N}$ and a single site on the west side of Haines Highway southeast of Haines Junction as rare in the Territory. Cody et al. (2000) reported another site in the south from about 80 kilometers northeast of the site adjacent to the Haines Highway. The specimen cited above is an extension of the range in the south of about 135 kilometers northwest of the site near the Haines Highway.

Saxifraga nelsoniana D. Don ssp. pacifica (Hultén) YUKON: wet organic soil with some fine scree at edge of stream, Tabletop Mountain, Kluane National Park, $61^{\circ} 15.231^{\prime} \mathrm{N} 139^{\circ} 11.115^{\prime} \mathrm{W}$, P. Caswell 285,29 June 2002 (DAO).

Douglas et al. (1981) considered this subspecies rare in the Territory. The specimen cited above is an extension of the known range in the Park of about 25 kilometers west of a site west of Kluane Lake.

Saxifraga rufopilosa (Hultén) Porsild - YUKON: moist places in $30^{\circ}$ southwest facing large talus dolomite boulders, summit of mountain on Canadian side of Mount Casca, 65²1'37"N 140 59'34"W, B. Bennett \& M. B. Cook 02-528, 27 June 2002 (DAO).
The specimen cited above is from a site about 35 kilometers northwest of the northernmost site south of latitude $66^{\circ} \mathrm{N}$ known to Cody (1996).

Saxifraga tricuspidata Rottb., Prickly Saxifrage YUKON: steep grassy slope on ridge northeast of Woodburn Creek, Tintina Trench, Ddhaw, $63^{\circ} 08^{\prime} \mathrm{N} 136^{\circ} 05^{\prime} \mathrm{W}$, C. E. Kennedy 7, 27 July 2001 (DAO).

The specimen cited above is an extension of the known range in the Territory (Cody 1996) of about 100 kilometers east northeast of a site at about longitude $137^{\circ} \mathrm{W}$, north of the Pelly River.

RosACEAE

Amelanchier alnifolia (Nutt.) Nutt., Saskatoon YUKON: southwest-facing slope across from Brittania Creek, Yukon River, 62 52'28"N 138 $42^{\prime} 56^{\prime \prime} \mathrm{W}, B$. Bennett 02-653, 10 Aug. 2002 (DAO).

Cody (1996) knew only three sites of this species north of the site reported above: Dawson City, Mayo, and adjacent to the Stewart River.

Chamaerhodos erecta (L.) Bge. ssp. nuttallii (Pickering ex Rydb.) Hultén - YUKON: common at base of southwest-facing slope, across from Brittania Creek, Yukon River, $62^{\circ} 52^{\prime} 28^{\prime \prime} \mathrm{N} 138^{\circ} 42^{\prime} 56^{\prime \prime} \mathrm{W}$, B. Bennett 02-640, 10 Aug. 2002 (DAO).

Cody (1996) knew this species in the Territory north to near latitude $64^{\circ}$. The specimen cited above is an extension of the known range in the Territory of about 80 kilometers west of a site adjacent to the Pelly River.

Dryas hookeriana Juz. - YUKON: Ogilvie Mountains, Tombstone Range, Yakamaw Creek, watershed east of Angelcomb Peak, $64^{\circ} 36^{\prime} \mathrm{N} 138^{\circ} 14^{\prime} \mathrm{W}$, Cody 36808 , 36845, 20-22 July 1999 (DAO); Dryas alaskensis tundra, Mount Casca border Monument, 65 $21^{\prime} 25^{\prime \prime} \mathrm{N}$ $141^{\circ} 00^{\prime} 00^{\prime} \mathrm{W}$, B. Bennett \& M. B. Cook 02-518, 27 June 2002 (B. Bennett Herbarium, photo DAO).

The specimens cited above are the first yet known to Cody (1996) from west of the Dempster Highway between latitudes $64^{\circ} \mathrm{N}$ and $66^{\circ} \mathrm{N}$.

Geum aleppicum Jacq. ssp. strictum (Ait.) Clausen, Yellow Avens - YuKON: Top of the World Golf Course, 64³'38"N 139²6'13"W, Cody \& Cody 37998, 25 July 2002 (DAO).

Douglas et al. (1981) considered this taxon rare in the Territory. The specimen cited above is an extension of the known range in the Territory of about 200 kilometers west of a site west of Keno City (Cody et al. 2001) and north of sites adjacent to the Alaska Highway near the Alaska border.

Geum rossii (R. Br.) Scr. - YUKON: moist places at summit of the Canadian side of Mount Casca, 65 $21^{\prime} 37^{\prime \prime} \mathrm{N}$ 14059'34"W, B. Bennett 02-524, 27 June 2002 (B. Bennett Herbarium, photo DAO).

The specimen cited above is from a site about 100 kilometers northwest of the nearest location in the Ogilvie Mountains where it has been collected frequently.

Potentilla arguta Pursh ssp. convallaria (Rydb.) Keck, Tall Cinquefoil - YuKon: dry rocky area, South Fork intake, Klondike River, $64^{\circ} 0$ '30"N 138 $12^{\prime} 00^{\prime \prime} \mathrm{W}, G$. Brunner 551, 22 July 2002 (DAO). 
The specimen cited above is only the second collected from north of latitude $64^{\circ} \mathrm{N}$ in the Territory (Cody 1996). It is from a site about 60 kilometers east of the vicinity of Dawson.

Rosa woodsii Lindl., Western Rose - YuKON: Artemisia frigida slope, east side of lake, Whitehorse, Hidden Lakes, $60^{\circ} 41^{\prime} 30^{\prime \prime} \mathrm{N} 135^{\circ} 02^{\prime} 45^{\prime \prime} \mathrm{W}$, B. Bennett 01 118, 11 July 2001 (B. Bennett Herbarium, photo DAO); grassy alkaline slope north of highway on slope, Alaska Highway Km 1588, 1 km east of Cracker Creek, $60^{\circ} 48^{\prime} 20^{\prime \prime N} 136^{\circ} 48^{\prime} 00^{\prime \prime W}$, B. Bennett 02-735, 11 Sept. 2002 (DAO); common at base of slope, Yukon River, Brittania Creek, 62 $52^{\prime} 28^{\prime \prime N} 138^{\circ} 42^{\prime} 56^{\prime \prime} \mathrm{W}$, B. Bennett 02-639, 10 Aug. 2002 (B. Bennett Herbarium, photo DAO).

This is a rare species in the Territory (Douglas et al. 1981). The first specimen cited above is only the fourth known in the Territory (Cody 1996). The second is an extension of the known range in the Territory (Cody 1996) of about 50 kilometers west of a site adjacent to the Alaska Highway. The third specimen is an extension of about 125 kilometers northwest of a site reported by Cody et al. (2003) from the vicinity of Carmacks.

\section{FABACEAE (LEGUMinOSAE)}

Lupinus nootkatensis Donn - YUKON: clearing between road and poplar forest, west side of Haines Highway, north of cut-off to Dalton Post, $60^{\circ} 09.405^{\prime} \mathrm{N}$ $136^{\circ} 58.572^{\prime} \mathrm{W}$, P. Caswell 440, 13 July 2002 (DAO).

The specimen cited above is only the third known from southeastern Kluane National Park and the Yukon Territory.

Oxytropis arctica R. Br., Arctic Oxytrope - YUKON: at base of talus slope, Lower Kathleen Lake, along south shore ca. $25 \mathrm{~km} \mathrm{SE}$ of Haines Junction, 60 $33^{\prime} \mathrm{N}$ 137²'W, G. W. \& G. G. Douglas 8391, 25 June 1975 (Kluane National Park, photo DAO); in alpine fell field, Dezadeash River Valley ca. $16 \mathrm{~km}$ WSW of Haines Junction, G.W. \& G.G. Douglas 8405, 30 June 1975 (Kluane National Park Herbarium, photo DAO).

Cody (1996) suggested that this species should be looked for in the mountains of northern Yukon Territory because it is known in the Canadian Arctic and northern Alaska. Douglas et al. (1999) included the Territory in the distribution of $O$. arctica presumably on the basis of the specimens cited above and also reported the only collection known in British Columbia from Mile 416 Alaska Highway which is about 700 kilometers east southeast of the Yukon sites. It should be added to the list of rare species in the Territory.

Oxytropis campestris (L.) DC. ssp. varians (Rydb.) Cody, Field Locoweed - YuKON: steep grassy slope on ridge northeast of Woodburn Creek, Tintina Trench, Ddhaw Ghro, $63^{\circ} 08^{\prime} \mathrm{N} 136^{\circ} 05^{\prime} \mathrm{W}$, C. E. Kennedy 6 , 27 July 2001 (DAO).

The specimen cited above is an extension of the known range in the Territory (Cody 1996) of about 110 kilometers northeast of a site adjacent to the Yukon River.

Trifolium pratense L., Red Clover - YuKON: roadside, junction of Campbell Highway and Frenchman Lake Road, 62 ${ }^{\circ} 30^{\prime \prime N} 135^{\circ} 30^{\prime} 55^{\prime \prime W}$, Cody \& Cody 37985, 24 July 2002 (DAO).
The nearest site of this introduced species in the Territory (Cody 1996) is from the vicinity of Whitehorse, about 150 kilometers to the south.

Vicia americana Muhl., American Vetch - YUKON: border of grassland and Populus, Macoobs Park, Mayo, $63^{\circ} 35^{\prime} 42.5^{\prime \prime} \mathrm{N} 135^{\circ} 56^{\prime} 57.1^{\prime \prime} \mathrm{W}$, Cody \& Cody 37668, 5 Aug. 2001 (DAO); west end of parking lot by visitor kiosk, Rancheria, 6005'16"N 130 36'10"W, B. Bennett 01-059, 26 July 2001 (DAO).

Douglas et al. (1981) considered this species rare in the Territory on the basis of a single collection from the Larsen Creek hotsprings in the extreme southeast (Scotter \& Cody 1979). Additional collections were added from this area by Cody et al. (1998) and from the vicinity of Watson Lake (Cody et al. 2000). The first specimen cited above is an extension of the known range in the Territory of about 550 kilometers to the northwest of Watson Lake. The second collection is an extension of the known distribution of about 120 kilometers west of Watson Lake but was probably introduced at that site.

\section{CAllitrichaceae}

Callitriche anceps Fern. - YUKON: on mud substrate at edge of water, old beaver pond east of Haines Highway about 10 kilometers south of Kathleen Lake cutoff, $60^{\circ} 30.838^{\prime} \mathrm{N} 137^{\circ} 04.970^{\prime} \mathrm{W}$, P. Caswell 787, 11 Aug. 2002 (DAO).

This species was considered rare in the Territory (Douglas et al. 1981). The specimen cited above is from a site about 30 kilometers northwest of a site in Kluane National Park.

\section{VIOLACEAE}

Viola renifolia Gray var. brainerdii (Greene) Fern., Kidney-leaved Violet - YUKON: humus covered with old poplar leaves, poplar and white spruce wood flat, Wade Lakes Road, between Kluane National Park and Haines Highway, $60^{\circ} 07.119^{\prime} \mathrm{N} 137^{\circ} 05.369^{\prime} \mathrm{W}$, P. Caswell 020, 6 June 2002 (DAO).

Cody (1996) knew this species as far north as the vicinity of Dawson City. The specimen cited above is an extension of the known range in the Territory of about 150 kilometers southwest of the vicinity of Whitehorse.

\section{HALORAGACEAE}

Myriophyllum verticillatum L. - YUKON: in water beside dock, Nunatuk Camp, 62 ${ }^{\circ} 49^{\prime \prime N} 135^{\circ} 48^{\prime} 4^{\prime \prime} \mathrm{W}$, Cody \& Cody 37989, 24 July 2002 (DAO).

Douglas et al. (1981) considered this species rare in the Territory. The specimen cited above is from a site about half way between the Pelly River and the north end of Lake Lebarge.

\section{APIACEAE}

Cicuta maculata L. var. angustifolia Hook., Spotted Water-hemlock - YUKON: lush herbaceous meadow on riverbank, Kirkman Creek, Yukon River, 62 ${ }^{\circ} 59^{\prime} 21^{\prime \prime} \mathrm{N}$ 139²3'07"W, B. Bennett 02-284, 10 Aug. 2002 (DAO).

Douglas et al. (1981) considered this taxon rare in the Territory. The specimen cited above is an extension of the known range of about 175 kilometers to the northwest of Carcross (Cody 1996).

Podistera macounii (Coult. \& Rose) Mathias \& Const. - Yukon: Dryas alaskensis tundra, Mount Casca bor- 


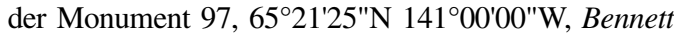
\& Cook 02-520, 27 June 2002 (DAO).

This species was considered rare in the Territory by Douglas et al. (1981). Cody (1996) knew it only from the Richardson Mountains area in the northeast. Cody et al. (1998) extended the known range in the Territory south into the Dawson range at latitude $62^{\circ} 26^{\prime} \mathrm{N}$. The specimen cited above is an extension of the known range in the Territory of about 275 kilometers to the west from the southernmost site in the Richardson Mountains.

\section{Pyrolaceae}

Pyrola minor L. - YUKON: adjacent to the Catholic Church, Fort Selkirk, 6246'34.4"N 137²3'35.9"W, Cody \& Kennedy 37815, 17 July 2002 (DAO).

Although quite frequent in the Territory east and north of the Klondike Highway, Cody (1996) also knew this species from the vicinity of southern Kluane Lake, to the west.

\section{ERICACEAE}

Cassiope tetragona (L.) D. Don ssp. saximontana (Small) Porsild - YuKON: dry alpine Dryas heath, summit of Mount Casca, 65²1'37"N 140 59'34"W, Bennett \& Cook 02-522, 27 June 2002 (DAO).

The specimen cited above is the northernmost yet found in the Territory. The nearest site to the above north of Chapman Lake in the Ogilvie Mountains is about 125 kilometers to the southeast (Cody et al. 2001).

Harrimanella stellariana (Pallas) Coville - YUKON: Morley River watershed, Englishman Range, 8 km SW of Morris Lake, northwest facing slope growing in bedrock controlled draw, 60²3'40"N 131 $47^{\circ} 50^{\prime \prime} \mathrm{W}$, J. Meikle 02-126, 20 June 2002 (DAO).

The specimen cited above is a rarity in the Territory (Douglas et al. 1981). It is a slight range extension north of the eastern site mapped by Cody (1996).

Phyllodoce glanduliflora (Hook). Cov., Yellow Mountain-heather - YUKON: subalpine slope by creek, Tank Creek, 6005'30"N 13441.9'W, S. Withers SW01-114, 15 July 2001 (DAO).

Cody (1996) knew this species in the Territory only from sites east of longitude $130^{\circ} \mathrm{W}$ and west of longitude $137^{\circ} \mathrm{W}$. The specimen cited above is about 125 kilometers east of a site in Kluane National Park.

Vaccinium membranaceum Dougl., Tall Blueberry YUKON: moist subalpine meadow, Kotaneelee Range, $60^{\circ} 14^{\prime} 31^{\prime \prime N} 124^{\circ} 7^{\prime} 19^{\prime \prime W}$, B. Bennett 98-149, 20 June 1998 (B. Bennett Herbarium, photo DAO); subalpine forest, Beavercrow Ridge, $60^{\circ} 12.865^{\prime} \mathrm{N} 124^{\circ} 35.79^{\prime} \mathrm{W}$, B. Bennett 98-310, (B. Bennett Herbarium, photo DAO).

Cody (1996) suggested that this species should be looked for in the southeastern part of the Territory. Cody et al. (1998) reported four collections from Mount Merrill and Gusty Lakes. The two specimens cited above are from the extreme southeast.

\section{PRIMUlaCEAE}

Douglasia alaskana (Cov. \& Standl.) Kelso - YUKON: eroded alpine slope, Table Mountain, Kluane National
Park, $61^{\circ} 15^{\prime} .231^{\prime} \mathrm{N} 139^{\circ} 11.115^{\prime} \mathrm{W}$, P. Caswell 282, 29 June 2002 (DAO).

Douglas et al. (1981) considered this species rare in the Territory where it was only known in Kluane National Park. The specimen cited above extends the known range in the Park about 75 kilometers to the northwest.

Douglasia arctica Hook. - YUKON: Cody et al. (2000) reported this species from a mountain between Kusawa and JoJo Lake, which was a considerable southward range extension.

The specimen upon which it was reported was unfortunately misidentified and the range extension should be deleted.

Primula eximia Greene (P. tschuktschorum Kjellm. ssp. cairnesiana A. E. Porsild) - YuKON: Dempster Highway about Km 96, at about altitude $4000 \mathrm{ft}$., $S$. Frisch, spring 2001 (DAO).

Douglas et al. (1981) considered this species rare in the Territory on the basis of collections from the northern Richardson Mountains and a site adjacent to the Alaska border at about $63^{\circ} 50^{\prime} \mathrm{N}$ latitude. The specimen cited above is from a site about 150 kilometers northeast of the Alaska border site where there was "a whole field of them".

Trientalis europaea L. s.1., Starflower - YUKON: damp mossy Picea glauca, Alnus incana, Dawson area, $64^{\circ} 02^{\prime} 00^{\prime \prime N} 137^{\circ} 41^{\prime} 30^{\prime \prime W}$, G. Brunner 439, 30 June 2001 (DAO).

The specimen cited above from about 70 kilometers east of Dawson City, is only the second collection in the Territory from north of latitude $64^{\circ} \mathrm{N}$ (Cody 1996).

\section{GentianacEAE}

Gentianella tenella (Rottb.) Boerner - YUKON: alpine barrens on long ridge, Atlas Mountain, Kluane National Park, $61^{\circ} 14.772^{\prime} \mathrm{N} 139^{\circ} 19.254^{\prime} \mathrm{W}$, D. Normandeau s.n., P. Caswell 328A, 6 July 2002 (DAO); patch of alpine tundra, mountain opposite Donjek Glacier, Kluane National Park, $61^{\circ} 11.859^{\prime} \mathrm{N} 139^{\circ} 23.372^{\prime} \mathrm{W}$, P. Caswell 619, 26 July 2002 (DAO).

This species was considered rare in the Territory by Douglas et al. (1981). Cody (1996) knew it from only three sites, two about 40 kilometers west of the specimens cited above and one just north of latitude $62^{\circ} \mathrm{N}$.

\section{Polemoniaceae}

Phlox hoodii Richards., Moss Phlox - YukON: dry rocky slope, open habitat, Donjek River watershed near Kluane Glacier, M. Hoefs 02-693, 4 July 2002 (DAO).

The specimen cited above from west of the Alaska Highway is the fifth and southernmost in that area. This species was not included in the Rare Vascular Plants of the Yukon (Douglas et al. 1981) because of its widespread distribution.

Polemonium acutiflorum Willd. forma lacteum Lepage - YUKON: rare in lush subalpine meadow at $4800 \mathrm{ft}$., mountain 4 miles west of Upper Hyland Lake, $62^{\circ} 03^{\prime} \mathrm{N}$ $128^{\circ} 59^{\prime} \mathrm{W}$, Calder \& Kukkonen 27889, 3 Aug. 1960 (DAO) (determined by B. Boivin 1970).

Lepage (1950) described this white-flowered form on the basis of a specimen collected at Anchorage, Alaska. Cody (1996) unfortunately did not mention this white form occurring in the Yukon Flora. 
Polemonium boreale Adams forma albiflorum Cody, - YUKON: fox den, sandy/grass area, Herschel Island, site $203,69^{\circ} 30^{\prime} \mathrm{N} 139^{\circ} 15^{\prime} \mathrm{W}$, C. E. Kennedy 262,16 July 1985 (DAO) (PARATYPE); [NorthWEST TERrITORIES: MACKENZIE: on a sandy portion of a gravel bar, Horton River, N.W.T., $69^{\circ} 42^{\prime} \mathrm{N} 126^{\circ} 56^{\prime} \mathrm{W}, G$. W. Scotter 101016b, 6 July 1995 (DAO) (HoLOTYPE) (Cody et al. 2003).

Cody (1996) stated that the corolla of this species was blue to violet or rarely white. The white form had not been described at that time.

\section{HydRoPHYLLACEAE}

Phacelia mollis Macb., Macbryde's Phacelia - YUKON: scattered in dry, open rubble on south-facing slopes near base of bluff, Moosehide Hills, Bluff on N side of Yukon R., $25 \mathrm{~km}$ downstream from Dawson, $64^{\circ} 15^{\prime} 41^{\prime \prime N} 139^{\circ} 36^{\prime} 13 " \mathrm{~W}$, C. Roland 93-27, 24 May 1993 (AKA, photo DAO).

The specimen cited above is an extension of about 50 kilometers to the southwest from the nearest site in the Ogilvie Mountains known to Cody (1996).

\section{BORAGINACEAE}

Eritrichium aretioides (Cham. \& Schlecht.) DC. YuKON: dry alpine Dryas heath, Canada/US Boundary Monument 97, 65 $21^{\prime} 25^{\prime \prime N} 141^{\circ} 00^{\prime} 00^{\prime \prime W}$, B. Bennett 02-019, 27 June 2002 (DAO).

The specimen cited above is an extension of the known range in the Territory of about 40 kilometers northwest of the nearest site known to Cody (1996) between latitudes $64^{\circ}$ and $66^{\circ} \mathrm{N}$.

Eritrichium chamissonis DC. - YUKON: vicinity of Snowdrift Camp, Vuntut National Park, $68^{\circ} 21.4^{\prime} \mathrm{N}$ $139^{\circ} 13.1^{\prime} \mathrm{W}, P$. Caswell PPC-Y-076, 19 June 2000 (B. Bennett Herbarium, photo DAO).

Cody (1996) knew this rare species in the Territory from only two localities in the British Mountains. The specimen cited above is from a site about 50 kilometers south of a site on Mt. Sedgwick.

Mertensia paniculata (Britt.) G. Don var. alaskana (Britt.) Williams - YUKON: adjacent to Joe Robert's Cabin, Fort Selkirk, 6246'34.4"N 137²3'35.9"W, Cody \& Kennedy 37796, 17 July 2002 (DAO).

Cody (1996) knew this variety only from south of latitude $61^{\circ} 30^{\prime} \mathrm{N}$ and north of latitude $67^{\circ} 30^{\prime} \mathrm{N}$.

Myosotis scorpioides L., Forget-me-not - YuKON: flower bed at Kluane Park Inn, Haines Junction, $60^{\circ} 44^{\prime} \mathrm{N} 137^{\circ} 31^{\prime} \mathrm{W}$, P. Caswell PPC-2000-Y-426, 28 Aug. 2000 (B. Bennett Herbarium, photo DAO).

This introduced species was previously known in the Territory only from the vicinity of Whitehorse (Cody 1996).

LAMIACEAE (LABIATAE)

Galeopsis tetrahit L. ssp. bifida (Boenn.) Fries, Hempnettle - YuKON: Forty Mile Historic Site at the confluence of the Forty Mile and Yukon rivers, $64^{\circ} 25^{\prime} \mathrm{N}$ $140^{\circ} 32^{\prime} \mathrm{W}$, C. E. Kennedy 2, 6 July 2000 (DAO); under large Picea glauca in squirrel midden, Judas Creek, $60^{\circ} 23.4^{\prime} \mathrm{N} 134^{\circ} 07.4^{\prime} \mathrm{W}$, S. Withers SW01-178, 30 Aug. 2001 (B. Bennett Herbarium, photo DAO).
This introduced species was previously known in the Territory from only three localities: North Canol Road (Cody 1994, 1996), Km 9 Dempster Highway (Cody et al. 1998) and Whitehorse (Cody et al. 2001). The first specimen cited above is the northernmost yet found in the Territory.

\section{SCROPHULARIACEAE}

Euphrasia subarctica Raup - YUKON: stony soil and moss in cleared area below rest stop, Klondike Highway $\mathrm{Km} 628,63^{\circ} 50^{\prime} 18.1^{\prime \prime N} 137^{\circ} 59^{\prime} 20.5^{\prime \prime W}$, Cody \& Cody 37660, 4 Aug. 2001 (DAO).

The specimen cited above is the northernmost yet found in the Territory (Cody 1996). It is from a site about 110 kilometers northwest/west of Mayo.

Mimulus guttatus DC., Yellow Monkeyflower YUKON: small seep near the road, Km 4.5 Atlin Road, $60^{\circ} 17^{\prime} 30^{\prime \prime} \mathrm{N} 133^{\circ} 50^{\prime} 3 " \mathrm{~W}$, S. Withers SW01-131, 24 July 2001 (DAO).

Douglas et al. (1981) considered this species rare in the Territory. The specimen cited above is from a site about 80 kilometers southeast of Whitehorse.

Pedicularis oederi Vahl., Oeder's Lousewort - YUKON: Herschel Island, $69^{\circ} 35^{\prime} \mathrm{N} 139^{\circ} 05^{\prime} \mathrm{W}$, C. E. Kennedy s.n., 30 July 1985 (Yukon Renewable Government Herbarium, photo DAO).

This species, which is frequent in the British Mountains to the south is now known to the north on Herschel Island.

Rhinanathus minor L. ssp. borealis (Sterneck) A. Löve - Yukon: gravel parking area at foot of trail to Rock Glacier, Haines Highway, $60^{\circ} 27^{\prime} 18^{\prime \prime} \mathrm{N} 137^{\circ} 03^{\prime} 37.6^{\prime \prime} \mathrm{W}$, Cody \& Cody 37894, 21 July 2002 (DAO).

This taxon is known in the Territory only as far north as about latitude $61^{\circ} 30^{\prime} \mathrm{N}$. The specimen cited above is the first record from the Haines Highway.

\section{OROBANCHACEAE}

Orobanche fasciculata Nutt. - YUKON: $45^{\circ}$ silty sand south-facing slope with Artemisia frigida and Calamagrostis purpurascens, Dutch Bluff, Yukon River, $61^{\circ} 55.72^{\prime} \mathrm{N} 135^{\circ} 03.99^{\prime} \mathrm{W}$, B. Bennett 02-290, 7 Aug. 2002 (DAO).

This species was considered rare in the Territory by Douglas et al. (1981). Cody et al. (2003) reported a new site in Kluane National Park adjacent to the Alaska Highway and southern Kluane Lake. The specimen cited above is from a site about 50 kilometers southeast of Carmacks.

\section{LENTIBULARIACEAE}

Pinguicula villosa L. - YUKON: in Sphagnum tussock, bog east of Haines Highway, $60^{\circ} 08.421^{\prime} \mathrm{N}$ $136^{\circ} 58.499^{\prime} \mathrm{W}$, P. Caswell 446, 13 July 2002 (DAO).

The specimen cited above is new to southwestern Yukon. It is an extension of the known range in the Territory of about 300 kilometers southwest from a site adjacent to the northern South Canol Road.

Utricularia minor L., Lesser Bladderwort - YUKON: shallow water of lake between Ross River and Campbell Highway, 6158'16"N 132 $38^{\circ} 06^{\prime \prime} \mathrm{W}$, Cody \& Cody 37967, 24 July 2002 (DAO).

This is a rare species in the Territory that Cody (1996) knew from only four sites between latitudes $60^{\circ} \mathrm{N}$ and $64^{\circ} 30^{\prime} \mathrm{N}$. 
Cody et al. (1998, 2000 and 2003) reported new collections from the southeast in the vicinity of La Biche River and in the far north between Trout Lake and the Babbage River. The specimen cited above is from about 150 kilometers north of a site near the south end of the South Canol Road.

\section{Plantaginaceae}

Plantago canescens Adams - YUKON: base of cliffs, talus, south-facing slope, Mount Carmacks, $64^{\circ} 20^{\prime} 08^{\prime \prime} \mathrm{N}$ $140^{\circ} 12^{\prime} 25^{\prime \prime W}$, B. Bennett 02-820, 24 Aug. 2002 (DAO).

The specimen cited above is an extension of the known range in the Territory of about 200 kilometers northwest of a site adjacent to the Klondike Highway (Cody 1996).

Plantago maritima L., Seaside Plaintain - YukON: dry sandy gravel slope north of gravel pit south of Alaska Highway, 60 $49^{\prime} 58^{\prime \prime N} 135^{\circ} 45^{\prime} 49^{\prime \prime} \mathrm{W}$, Cody \& Cody 38204, 1 Aug. 2002 (DAO).

This species was considered rare in the Yukon Territory by Douglas et al. (1981). Cody (1996) knew it from only two localities adjacent to Kluane Lake in the extreme southwest. The specimen cited above is from a site about 100 kilometers to the east.

\section{CAPRIFOLIACEAE}

Sambucus racemosa L. ssp. pubens (Michx.) House, Red Elderberry - YUKON: roadside and lakeshore, Wade Lakes, $60^{\circ} 05.0^{\prime} \mathrm{N} 137^{\circ} 19.6^{\prime} \mathrm{W}$, R. Maraj s.n., 14 Sept. 2002 (DAO).

Douglas et al. (1981) (as var. arborescens) knew this taxon from a single locality in southern Kluane National Park. The specimen cited above extends the known range about 80 kilometers to the east between the park and Haines Highway.

\section{VALERIANACEAE}

Valeriana sitchensis Bong., Sitka Valerian - Yukon: Site YPN 120, 6306'39.8"N 133²0'15"W, G. Brunner 569-01, 6 Aug. 2001 (Environment Yukon, photo DAO).

The specimen cited above is from a site between the North Canol Road and Mayo.

\section{Asteraceae (COMPOSITAE)}

Aster alpinus L. ssp. vierhapperi Onno, Alpine Aster - YUKON: steep grassy slope on ridge, northeast of Woodburn Creek, Tintina Trench, Ddhaw Ghro, $63^{\circ} 08^{\prime} \mathrm{N} 136^{\circ} 05^{\prime} \mathrm{W}$, C. E. Kennedy 2, 27 July 2001 (DAO).

The specimen cited above is an extension of the known range in the Territory (Cody 1996) of about 100 kilometers northeast of a site near the junction of the Pelly and Yukon rivers.

Aster falcatus Lindl., Western Heath Aster - YUKON: lush herbaceous meadow riverbank, Kirkman Creek, Yukon River, 62 $59^{\prime} 21^{\prime \prime N} 139^{\circ} 23^{\prime} 07^{\prime \prime W}$, B. Bennett 02-673, 10 Aug. 2002 (B. Bennett Herbarium, photo DAO).

Douglas et al. (1981) considered this species rare in the Territory. The specimen cited above is from a site about 150 kilometers west of a site adjacent to the Klondike Highway.

Erigeron caespitosus Nutt. - YUKON: silty sand southfacing slope, Dutch Bluff, Yukon River, 61⒌72'N $135^{\circ} 03.99^{\prime} \mathrm{W}$, B. Bennett 02-300, 7 Aug. 2002 (DAO); top of slope of open bank, 1 mile upstream of Big Salmon, on Yukon River, $61^{\circ} 51.41^{\prime} \mathrm{N} 134^{\circ} 55.01^{\prime} \mathrm{W}$, B. Bennett 02-302, 7 Aug. 2002 (DAO); base of cliffs, talus, south-facing slope, Yukon River, Mount Carmacks, $64^{\circ} 20^{\prime} 08^{\prime \prime} \mathrm{N} 140^{\circ} 12^{\prime} 25^{\prime \prime} \mathrm{W}, B$. Bennett \& $R$. Mulder 02-816, 24 Aug. 2002 (DAO).

The first specimen cited above is from a site about 75 kilometers southeast of a site adjacent to Carmacks and the second specimen is from a site about 120 kilometers southeast of Carmacks. The third specimen is from a site between two sites near the Alaska border, one to the south about 120 kilometers and the other to the north about 100 kilometers (Cody 1996).

Erigeron hyperboreus Greene - YUKON: middle of dirt road leading to Copper Joe Creek Road, Kluane National Park, $61^{\circ} 18.688^{\prime} \mathrm{N} 138^{\circ} 56.319^{\prime} \mathrm{W}$, P. Caswell 170, 24 June 2002 (DAO).

This species was considered as rare in the Territory by Douglas et al. (1981). The specimen cited above is an extension of about 425 kilometers south of a site northwest of Dawson City.

Senecio eremophilus Richards., Dryland Ragwort (Figure 6) - Yukon: Pine Creek Campground, 4 miles east of Haines Junction, Mile 1012 Alaska Highway, V. L. Harms 6299, 17 August 1968 (DAO).

The specimen cited above is the first known record in the Yukon Territory where it was probably introduced. To the

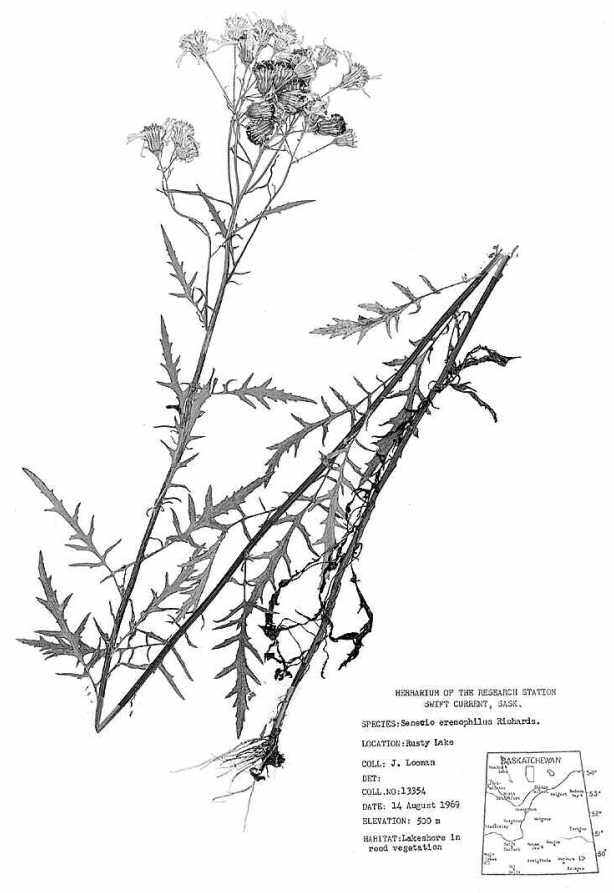

FiguRE 6. Senecio eremophilus, Dryland Ragwort (drawn by J. Looman). 
west in Alaska, Hultén (1968) knew it only from the vicinity of Tok where he considered it also to be introduced. To the east Porsild and Cody (1980) knew it from the Slave River area north of Fort Smith where it was found in damp woodland meadows and adjacent to roadsides and considered native. To the south it is found in eastern British Columbia east to Manitoba and south into the United States. It can be separated from $S$. sheldonensis as follows:

A. Stem leaves deeply incised, not reduced upwards .............. eremophylus

B. Stem leaves with merely repand-denticulate margins, reduced upwards .......S. sheldonensis

Solidago canadensis L. var. salebrosa (Piper) Jones YUKON: beside test plot, $1 \mathrm{~km}$ N of Montague Roadhouse, Km 132 Klondike Highway, 6149'35"N 136 ${ }^{\circ} 52^{\prime \prime W}$, Cody \& Cody 38073, 28 July 2002 (DAO).

Douglas et al. (1981) considered this species rare in the Territory. The specimen cited above is from about 90 kilometers southwest of a site mapped by Cody (1996).

Sonchus arvensis L. ssp. uliginosus (Bieb.) Nyman, Perennial Sow-thistle - YuKON: roadside gravel, Alaska Highway $3 \mathrm{~km}$ west of Kusawa Lake turnoff below microwave tower, 60 $46^{\prime} 00^{\prime \prime} \mathrm{N} 136^{\circ} 05^{\prime} 36^{\prime \prime} \mathrm{W}, \quad B$. Bennett 02-749, 11 Sept. 2002 (DAO).

The specimen of this introduced species cited above is from a site between Whitehorse and Haines Junction.

Tanacetum vulgare L., Common Tansey - YUKON: in distributed ground along Campbell Highway, Tuchitua River, 6056'N 129 $13^{\circ} 00^{\prime \prime} \mathrm{W}, R$. Rosie 1959, 16 Aug. 1997 (DAO); single patch west of the boat launch, Yukon River Bridge, 60³4'20"N 134 $40^{\prime} \mathrm{W}$, B. Bennett 01-063, 19 Aug. 2001 (DAO).

The specimens cited above are only the second and third records of this introduced species in the Territory. Cody et al. (1998) reported the first collection from just north of Kathleen Lake Lodge on the Haines Highway.

\section{Acknowledgments}

We thank Donald Britton and Daniel Brunton for their identification of Isoetes; Stephen J. Darbyshire for his identification of several Poaceae; Gerald Mulligan for his identification of Brassicaceae specimens; Heidi Solstad for her identification of Papaver croceum; Greg Brunner, Manfred Hoefs, Jennifer Line, R. Maraj, Rhonda Rosie and Stu Withers for their contributions; Margaret Cody and Douglas Cody for assisting the senior author in the summers of 2001 and 2002 in southern Yukon; artist Lee Mennell for his art work; Paul Catling for reviewing an earlier version of this manuscript, and especially Leslie Cody for the many hours inputting this information on her computer.

\section{Literature Cited}

Cody, W. J. 1994. The Flora of the Yukon Territory: Additions, Range Extensions and Comments. Canadian FieldNaturalist 108: 428-479.

Cody, W. J. 1996. Flora of the Yukon Territory. National Research Council (NRC) Press, Ottawa, Ontario, Canada. 643 pages.

Cody, W. J. 2000. Flora of the Yukon Territory - Second Edition. National Research Council (NRC) Press, Ottawa, Ontario, Canada. 669 pages.

Cody, W. J., C. E. Kennedy, and B. Bennett. 1998. New Records of Vascular Plants in the Yukon Territory. Canadian Field-Naturalist 112: 289-328.

Cody, W. J., C. E. Kennedy, and B. Bennett. 2000. New Records of Vascular Plants in the Yukon Territory II. Canadian Field-Naturalist 114: 417-443.

Cody, W. J., C. E. Kennedy, and B. Bennett. 2001. New Records of Vascular Plants in the Yukon Territory III. Canadian Field-Naturalist 115: 301-322.

Cody, W. J., C. E. Kennedy, B. Bennett, and V. Loewen. 2002. New records of Vascular Plants in the Yukon Territory IV. Canadian Field-Naturalist 116: 446-474.

Cody, W. J., C. E. Kennedy, B. Bennett, and J. Staniforth. 2003. New records of Vascular Plants in the Yukon Territory V. Canadian Field-Naturalist 117: 278-301.

Cody, W. J., K. L. Reading, and J. L. Line. 2003. Additions and range extensions to the vascular plant flora of the Continental Northwest Territories and Nunavut, Canada II. Canadian Field-Naturalist 117(3): 448-465.

Douglas, G. W., G. W. Argus, H. L. Dickson, and D. F. Brunton. 1981. The rare vascular plants of the Yukon. Syllogeus 28: 1-96.

Hulten, E. 1941-1950. Flora of Alaska and Yukon, 1-10. Lunds Universitets Arsskrift, N. F. Aud. 2. Volumes 3746. 1902 pages.

Hulten, E. 1968. Flora of Alaska and neighboring territories. Stanford University Press. Stanford, California. 1008 pages.

Kojima, S., and R. C. Brooks. 1985. An annotated vascular flora of areas adjacent to the Dempster Highway, central Yukon Territory. I. Pteridophyta, Gymnospermae and Monocotyledonae. British Columbia Provincial Museum, Contributions of Natural Science 31: 1-16.

Lepage, E. 1950. Variations mineures de quelques plantes du nord-est du Canada et de l'Alaska. Le Naturaliste canadien $77: 228-231$.

McJannet, C. L., G. W. Argus, and W. J. Cody. 1995. Rare vascular plants in the Northwest Territories. Syllogeus 73: 1-104.

Porsild, A. E. 1975. Materials for a flora of central Yukon Territory. National Museum of Natural Sciences. Publications in Botany 4, Ottawa, Ontario. 77 pages.

Porsild, A. E., and W. J. Cody. 1980. Vascular plants of Continental Northwest Territories, Canada. National Museum of Natural Sciences, Ottawa, Ontario. 667 pages.

Scotter, G. W., and W. J. Cody. 1979. Interesting vascular plants from southeastern Yukon Territory. Canadian FieldNaturalist 93: 163-170.

Welsh, S. L. 1974. Anderson's Flora of Alaska and Adjacent Parts of Canada. Brigham Young University Press, Provo, Utah, U.S.A. 724 pages.

Received 11 December 2003

Accepted 3 February 2004 